\title{
POTENTIAL URANIUM HOST ROCKS AND STRUCTURES IN THE CENTRAL GREAT PLAINS
}

UNIVERSITY OF KANSAS:

E. J. Zeller, G. Dreschhoff, E. Angino, K. Holdoway,

W. Hakes, G. Jayaprakash, and K. Crisler

Texas Instruments Incorporated:

D. F. Saunders

THE UNIVERSITY OF KANSAS

Radiation Physics Laboratory

Space Technology Center

November 15, 1975

PREPARED FOR THE U.S. ENERGY RESEARCH AND DEVELOPMENT ADMINISTRATION GRAND JUNCTION OFFICE

UNDER CONTRACT NO. AT(05-1)-1642 


\section{LEGAL NOTICE}

This report was prepared as an account of work sponsored by the United States Government. Neither the United States nor the United States Energy Research and Development Administration, nor any of their employees, nor any of their contractors, subcontractors, or their employees, makes any warranty, express or implied, or assumes any legal liability or responsibility for the accuracy, completeness or usefulness of any information, apparatus, product or process disclosed, or represents that its use would not infringe privately owned rights. 
POTENTIAL URANIUM HOST ROCKS AND STRUCTURES IN THE CENTRAL GREAT PLAINS

UNIVERSITY OF KANSAS:

E.J. Zeller, G. Dreschhoff, E. Angino, K. Holdoway, W. Hakes, G. Jayaprakash, and K. Crisler

\title{
TEXAS INSTRUMENTS INCORPORATED:
}

D. F. Saunders

\begin{abstract}
THE UNIVERSITY OF KANSAS
Radiation Physics Laboratory

Space Technology Center
\end{abstract}

November 15, 1975

Prepared for

U.S. ENERGY RESEARCH AND DEVELOPMENT ADMINISTRATION Grand Junction Office

Under Contract No. AT(05-1)-1642 



\section{ABSTRACT}

The University of Kansas in conjunction with the Kansas Geological Survey and Texas Instruments Incorporated completed a preliminary study of the uranium potential of the Central Great Plains sponsored by the Energy Research and Development Administration.

The study area extends from longitude $99^{\circ}$ to $104^{\circ} \mathrm{W}$ and is bounded by the North Platte River on the north and the Canadian River on the south. This region has no known commercial uranium accumulations, but is an area which contains formations with similar facies that are known to have deposits in other areas.

A new method of utilizing petroleum exploration gamma-ray well log data was tested in the western Kansas portion of the survey area. Gamma activities in the Dakota and Morrison formations were computerprocessed by trend surface analysis, statistically analyzed, and the anomalies were compared with regional geomorphic lineaments derived from satellite imagery as well as regional geology, to draw conclusions as to their origin and significance.

Conclusions are:

1) Possible uraniferous provinces have been outlined in the subsurface of western Kansas

2) The new well log data approach can be used to define potential uraniferous provinces in any well-explored petroleum region.

3) The close spatial correlation between anomalies and regional geomorphic lineaments provides strong support for the concept that the lineaments represent vertical fracture zones which can act as preferred pathways for vertical fluid migration. 
4) The location of the strongest anomalies over impervious salt bodies indicates that any uranium bearing mineralizers must have moved down through the geologic section rather than upward.

Recommendations are made to extend the application of the well-log approach, to do drilling and sampling to prove whether the anomalies are really due to uranium, and to add geobotanical and emanometric measurements during future studies. 
TABLE OF CONTENTS

Section

Title

Page

ABSTRACT

iii

I

$\begin{array}{ll}\text { INTRODUCTION } & \text { I- } 1\end{array}$

A. GENERAL I-1

B. LOCATION AND GEOGRAPHIC SETTING I-2

C. KNOWN URANIUM OCCURRENCES AND I-3 POTENTIAL

D. URANIFEROUS PROVINCE CONCEPT I-4

E. SPECIAL PROBLEMS IN UR ANIUM RESOURCE I-5 EVALUATION RELATED TO THE GEOLOGY OF THE CENTRAL GREAT PLAINS

F. ACKNOW LEDGMENTS I-6

II GAMMA-RAY WELL LOG ANALYSIS II-1

A. GENERAL $\quad$ II -1

B. LOG INTERPRETATION METHODS AND II-1 LIMITATIONS

C. ISORAD MAPS II -3

D. INTERPRETATION OF ISORAD MAPS II-9

E. DISTRIBUTION OF DAKOTA HIGHEST VALUES II-11

F. STRATIGRAPHIC SECTIONS II-11

G. NEAR -SURFACE GAMMA-RAY WELL LOG II-17 ANOMALIES

III REGIONAL LANDSAT (ERTS) LINEAMENT STUDY II-1

A. GENERAL III- 1

B. PREPAR ATION OF REGIONAL LINEAMENT MAPS III-2

C. RELATIONSHIP OF LINEAMENTS TO WELL UI-3 LOG DATA

D. POTENTIAL APPLICATION OF LINEAMENTS III- 5 IN UR ANIUM RECONN AISSANCE

1. Lineament Detection by Surface Gamma-Ray III-5 Spectrometry

2. Regional Geomorphic Lineament Map of the III-5 Central Great Plains

E. THE INF LUENCE OF UNDER LYING SALT III-6 DEPOSITS ON THE DEPOSITION OF URANIUM 
TABLE OF CONTENTS (CONTD)

Section

Title

Page

IV

ROAD TRAVERSES AND SURFACE FIELD

IV -1

INVESTIGATIONS

A. GENERAL

IV -1

B. TRAVERSES ACROSS REGIONAL LINEAMENTS

IV -3

C. DESCRIPTIONS OF INDIVIDUAL LOCALITIES

IV -4

1. Locality 1

2. Locality 2

IV -4

3. Locality 3

IV -4

4. Locality 4

IV -5

5. Localities 5 and 6

IV -6

6. Locality 7

IV -6

7. Locality 8

IV -6

8. Locality 9

IV -7

IV -7

$\mathrm{V}$

SUMMARY OF CONCLUSIONS

$\mathrm{V}-1$

A. GAMMA-RAY WELL LOG DATA

$\mathrm{V}-1$

B. REGIONAL LANDSAT (ERTS) LINEAMENT STUDY

$\mathrm{V}-1$

C. RELATIONSHIP OF ANOMALIES TO SALT BEDS

$\mathrm{V}-2$

VI RECOMMENDATIONS FOR FUTURE INVESTIGATIONS

VI- 1

A. GENERAL

VI- 1

B. EXTENSION OF GAMMA-RAY WELL LOG DATA

VI -1 EVALUATION

C. DRILLING AND SAMPLING PROGRAM

VI-2

D. GEOBOT ANICAL STUDY

$\mathrm{VI}-3$

E. AIRBORNE GAMMA-RAY SPECTROMETRY

$\mathrm{VI}-3$

F. SURFACE SUR VEYS

VI-3

G. EXPANSION OF STUDY AREA

$\mathrm{VI}-4$

VII

REFERENCES

VII -1 


\section{ILLUSTRATIONS}

Figure

Description

Page

I-1 Index Map of Study A rea Showing Geologic Section

I-2 Locations

II- I Probability Plot for Morrison Fm. Average Values II-5

II-2 Probability Plot for Dakota Fm. Average Values II 6

$\begin{array}{lll}\text { II }-3 & \text { Histograms } & \text { II }-7\end{array}$

II-4 Stratigraphic Section - Nebraska II- 12

II-5 Stratigraphic Section - Colorado II-13

II-6 Stratigraphic Section - Kansas II-14

II-7 Stratigraphic Section - New Mexico II-15

II-8 Stratigraphic Section - Oklahoma II-16

III-1 Distribution of Salt of Permian Age in the Central III-8

Mid-Continent Region

III-2 Relationship Between Salt Bodies and Significant III-9 Radioactive Anomalies

IV - 1 Road Traverses and Study Localities $\quad$ IV -2

\section{TABLES}

Table

Title

Page

II-1 Statistical Parameters - Well Log Data II-8

II-2 Single - and Multiple-Point Probabilities II-9 
PLATES

Plate

Title

II-1 Isorad Contour Map of Morrison Formation Average Gamma-Ray Log Values

II-2 Isorad Contour Map of Dakota Formation Average GammaRay Log Values

II-3 Isorad Contour Map of Gamma-Ray Log Values for Top Portion of the Dakota Formation

II-4 Isorad Contour Map of Gamma-Ray Log Values for Bottom Portion of the Dakota Eormation

II-5 Highest Gamma-Ray Log Values in the Dakota Formation

II-6 Near-Surface Gamma-Ray Well Log Analysis

III-1 Regional LANDSAT (ERTS) Geomorphic Lineament Map North Part of Study Area

III-2 Regional LANDSAT (ERTS) Geomorphic Lineament Map South Part of Study Area 


\section{SECTION I}

\section{INTRODUCTION}

\section{A. GENERAL}

This report covers the results of an ERDA-sponsored study to provide a preliminary evaluation of the uranium potential of the central portion of the Great Plains. It was carried out by the University of Kansas under contract number AT $(05-1)-1642$. This work is part of the ERDA National U ranium Resource Evaluation (NURE) Program. Texas Instruments Incorporated contributed to the study as a subcontractor.

It was initially planned to conduct a literature study to determine the identity and location within the survey area of any known uranium occurrences and potential uraniferous host rocks based on their characteristcs and the general principles of uranium geochemistry and geology. This was to be supplemented by a geomorphic lineament study using satellite imagery as well as field traverses to attempt to delineate potential uraniferous provinces. The literature and geomorphic lineament studies we re completed; however, weather conditions severely limited the amount of field work, and anothe $r$ better approach was developed to map the potential uraniferous provinces in the Kansas portion of the survey area. This was based on the study of the Kansas Geological Survey library of gamma-ray well logs from oil wells. The overall result of this change in direction of effort was that the Kansas portion of the area was evaluated more thoroughly than the remainder, and a new approach in uranium province delineation was developed. This technique may prove to be of considerable value in detecting uraniferous provinces in buried potential host rocks in areas where fairly extensive oil exploration has been done. 


\section{B. LOCATION AND GEOGRAPHIC SETTING}

The study area lies between the 99 th meridian on the east and the 104th meridian on the west. It is bounded on the north by the North Platte River and on the south by the Canadian River. Portions of the states of Kansas, Colorado, Nebraska, Oklahoma, Texas, and New Mexico are included in the project boundaries (see Figure $I-1$ ). The region comprises a major portion of the Central Great Plains and, except for the southwestern corner, is generally of low relief with limited outcrops of bedrock. A large portion of the surface is covered with clastic deposits of terrestrial origin which were derived from the Rocky Mountains during previous periods of uplift and erosion.

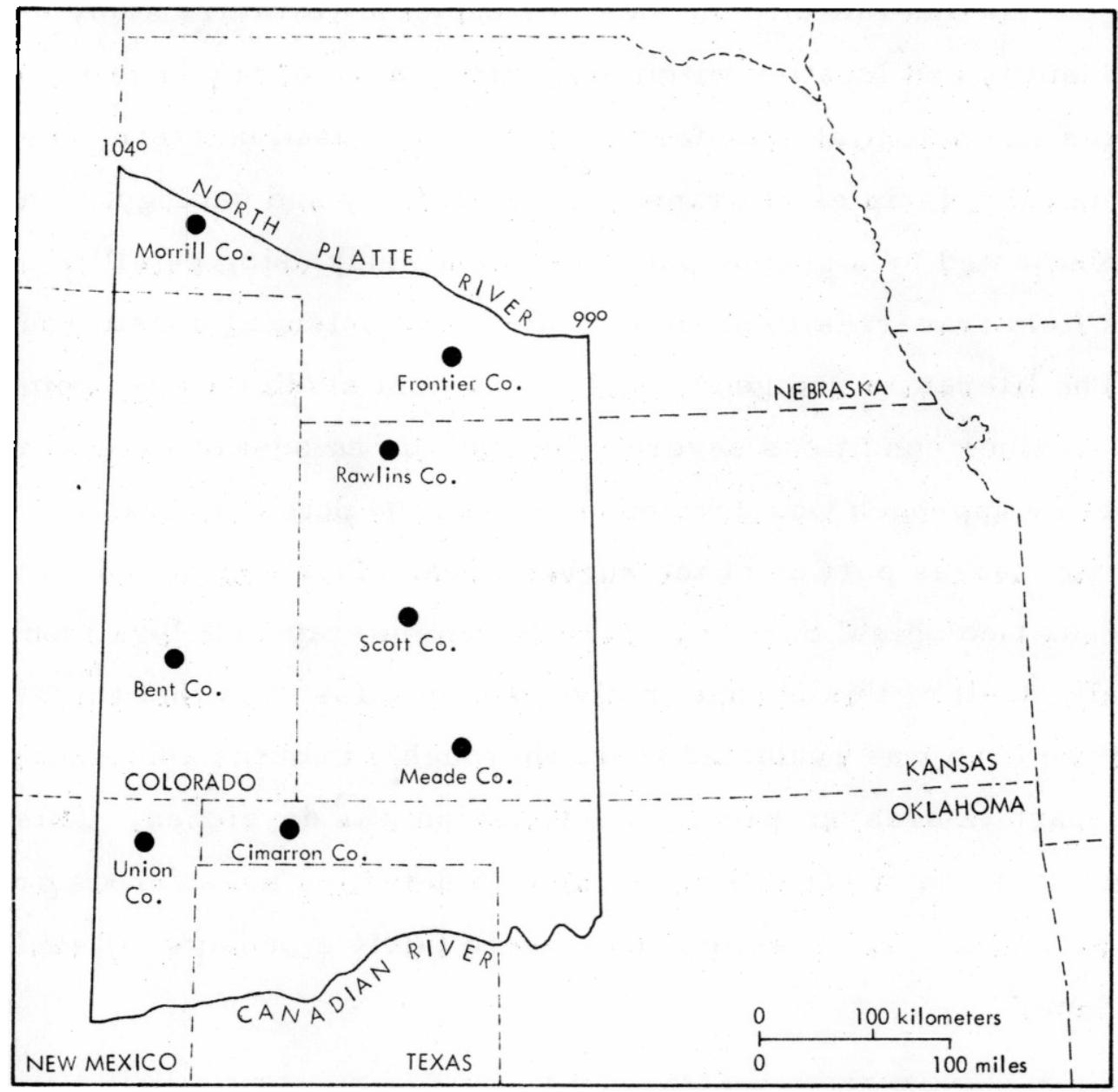

Figure I-1. Index Map of Study Area Showing Geologic Section Locations (see Section $\amalg-E$ ) 


\section{KNOWN URANIUM OCCURRENCES AND POTENTIAL}

More than 20 years ago Nininger (1954) indicated this region to be favorable for Colorado Plateau-type deposits of uranium. Potential host beds known to be uraniferous elsewhere are present in the area, including formations of Tertiary, Cretaceous, Jurassic, and Triassic age. Malan (1972) suggested this general area to be favorable for stratiform deposits, particularly in Tertiary host rocks, based on the regional pattern of uranium enrichment in Precambrian inferred source rocks for the sediments.

To date very little exploratory work has been done in the survey area, and no deposits of commercial size and grade are known. Butler, Finch, and Twenhofel (1962); Finch, Parrish, and Walker (1959); and Finch (1967) have shown the locations of the known uranium deposits in the U.S. Within the study areas only four occurrences have been reported (see Figure IV - 1). They are all in Colorado and are described by Finch (1967) as follows:

\section{Finch's}

No.

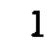

81

82

83
Identity

Name unknown

Name unknown

Name unknown

Booster No. 1
Host Rock

White River

Morrison (?)

Morrison (?)

Dakota/Morrison

Comprehensive bibliog raphies on the geology and uranium deposits of this region are presented by Cooper (1953, 1954, 1955); Krusiewski (1970); and Finch, W right, and Sullivan (1975).

Finch (1967) presents a detailed listing of formations known to contain uranium deposits in sandstone together with a summary of the geologic characteristics of these units.

Other types of known concentrations of uranium in this survey area include black shales, notably the Sharon Springs member of the Pierre 
Shale (Tourtelot, 1956; Swans on, 1960), and uraniferous asphaltic rock which overlies the gas reservoir in the Panhandle gas field (Pierce, Gott, and Mytton, 1964). Although these occurrences are not commercially exploitable at present, they may become important eventually and their distribution can be of assistance in defining uraniferous provinces within the Central Great Plains area.

The Sharon Springs member of the Pierre Shale contains on the ave rage about $10 \mathrm{ppm} U$ with selected beds running between 40 and $50 \mathrm{ppm} \mathrm{U}$ (Landis, 1959). It is conceivable that it could eventually become an exploitable very low grade source of both oil and uranium.

Pie rce, Gott and Mytton (1964) concluded that the uraniferous asphaltic sediments could be the source of the helium in the Panhandle gas field leading to the concept that the presence of helium-bearing natural gases may be a valuable indicator of potential uraniferous provinces in their general vicinity.

\section{URANIFEROUS PROVINCE CONCEPT}

- From a broad regional viewpoint it has been observed that known uranium deposits are g rouped generally in areas characterized by somewhat higher uranium content in:

- Ground waters (Scott and Barker, 1958)

- Igneous rocks (Everhart, 1958)

- Possible Precambrian source areas for stratiform deposit host rocks (Malan, 1972)

On a somewhat more local scale Darnley (1973) showed that these "uraniferous provinces" could be detected and mapped using highsensitivity airborne gamma-ray spectrometers. They may be used in 
regional reconnaissance for economic uranium deposits following the concept that new uranium finds will be made more frequently in such areas than in areas where the uranium content in associated soils, rocks and groundwaters is comparatively low.

\section{E. SPECIAL PROBLEMS IN URANIUM RESOURCE EVALUATION RELATED} TO THE GEOLOGY OF THE CENTRAL GREAT PLAINS

Before proceeding to the evaluation of the uranium potential of the Central Great Plains, it may be appropriate to summarize the ways in which the exploration techniques must differ from those conventionally applied in the Rocky Mountain province. In any prospecting prog ram the successto-failure ratio is not a simple relationship between the areal extent of the prospecting district and the physical size of the target mineral deposits. Clearly, the ability of the prospector to recognize potentially favorable targets is a major factor in his probable success. In the Rocky Mountains, the target is frequently readily recognizable because of the good quality of the exposures. However, in the Central Great Plains, the target deposits are most likely to be hidden under an overburden which does not reveal substantial information about their structure or extent.

Since lack of bedrock outcrops limits direct observation of favorable host zones, a much heavier reliance must be placed on subsurface techniques. Data obtained from bore holes assume a much more significant role in the preliminary evaluation of the Plains than would be the case in the Rocky Mountain province. Obviously, however, the density of bore hole information will not be very high and the small-scale lateral variations in sedimentary facies which are often critical to emplacement of uranium ore bodies will be more difficult to trace than they are in the Rocky Mountain region.

Direct observation of outcrops is limited but the lack of such outcrops must not be interpreted as a lack of potential deposits. In the 
Rocky Mountain region substantial portions of many deposits may have been lost to erosion. On the plains any deposits which do exist are probably still present and erosional losses have been minimal.

In the Great Plains area it appears that substantial quantities of the source material from which uranium deposits might be derived are still retained. Furthermore it appears that weathering and decomposition of some of these deposits is releasing uranium to ground and surface waters and the deposition of uranium in favorable host rocks may be going on at the present time. In veiw of this fact it is clear that much more attention must be given to the nature and distribution of source materials and to their hydrologic environment in the Great Plains region.

Although much of the foregoing discussion is obvious, it has been included to remind the reader that the direct transfer to the Central Great Plains of methods and thinking which have been highly successful in the Rocky Mountains province could result in unwarranted discouragement and lack of success. This could cause the abandonment of an a rea which, in fact, may have a high, real potential for uranium resources.

\section{F. ACKNOẂLEDGMENTS}

The research conducted during the course of this project was both facilitated and expanded by the aid furnished by the Kansas State Geological Survey. Dr. William Hambleton, Kansas State Geologist, provided financial support to permit gathering well log data in Kansas east of the project boundary. Through his cooperation the time and facilities of the Geological Research and Operations Research Sections we re made available for data processing and computer plotting. The aid of their staffs was greatly appreciated. Dr. Pieter Berendsen of the Mineral Resources Section furnished the facilities for core drilling at Kanopolis State Lake and the Geochemistry 
Section performed analyses on a number of samples. In addition, the staff of the well log librarywas especially helpful in expediting the collection of well log data in Kansas. The office of the U.S. Geological Survey in Garden City, Kansas also provided valuable information on groundwate $r$ circulation in western Kansas.

We also wish to thank Dr. Raymond R. Burchett of the Conservation and Survey Division of the University of Nebraska for discussions and access to the Nebraska well log library. The Anadarko Production Company of Denver, Colorado also provided valuable aid and subsurface data in eastern Colorado. 



\section{SECTION II \\ GAMMA-RAY WELL LOG ANALYSIS}

\section{A. GENERAL}

Data obtained from drill holes becomes especially important in attempting any regional evaluation of the uranium potential of rocks in an area of nearly horizontal bedding and low relief. This is particularly true in regions which are lacking broad-scale surface radioactivity surveys and in which active uranium prospecting has been minimal. Since this is clearly the case in the study area, it was concluded that a substantial effort should be made to attempt to use all available radiation measurements of rocks in the area for assessing its uranium potential. Neither time nor funding was adequate to permit the entire study area to be surveyed by this method, but through the cooperation of the Kansas Geological Survey, which provided partial funding for the program, it was possible to examine all of the state of Kansas which lies west and north of the Mesozoic outcrop boundary.

Each county was examined to determine the availability of wells which had gamma-ray logs extending from the surface downward. Since gamma-ray logging is frequently limited to the zones of interest for petroleum production, most of the well logs we re unsuitable for the study. It was, however, possible to obtain usable logs from approximately 335 wells scattered with rough uniformity over the area.

\section{B. LOG INTERPRETATION METHODS AND LIMITATIONS}

In order to test the potential usefulness of gamma-ray logs from oil drilling for assessing uranium potential, specific stratigraphic zones were chosen. In this case the Morrison and Dakota were selected because they are widespread over the area and they are easily identifiable in logs. 
Furthermore, these formations produce uranium in the Rocky Mountain area from zones which are lithologically similar to those in the study area. Their selection for this test of the method must not be interpreted as implying that they are the only formations present which have significant uranium potential (see Section II-F).

Before proceeding to any discussion of the maps, it is necessary to examine the limitations of both the data and its treatment to produce the maps.

First, it must be assumed that the various well logging service companies make use of standardized radiation counters in their bore hole logging operations. Modern logs are calibrated in API units. Many of the older well logs made use of a standard which was calibrated in units of grams Radium equivalent per ton. A conversion factor of 16.5 API units per one old $\mathrm{g} . \mathrm{Ra}$ eq/ton can be used in cases where GNT-F or G gamma-ray logs were used, and a factor of 11.7 API units per old g. Ra eq/ton must be used for GNT-J K gamma-ray logs (Schlumberger, 1972).

In spite of the fact that these calibration factors are fixed quantities, it must be recognized that gamma-ray measurements on individual wells may not be comparable on a strict quantitative basis with those of adjacent wells. A qualitative check of the gamma-ray response can be made, however, by comparing the measured intensities from some stratigraphic zones which are known to be of uniform lithology over large areas. In this study any logs which showed either uniformly low or uniformly high readings were rejected on the assumption that they resulted from faulty calibration. In logs run after 1965 , such instances are rare.

Anothe $r$ problem encountered in the interpretation of well $10 \mathrm{~g}$ data results from the effect of casings on the gamma activity which is measured (see Gott and Hill, 1953). The obvious effect is shielding due to the 
steel casing which reduces the total gamma-ray flux reaching the counter probe. Casing locations are usually marked clearly in most logs and these zones can be avoided. A more serious problem arises from the entry of formation liquids or gases into the well around the end of a casing. This is especially significant where the gamma-ray logging was not performed immediately after completion of the well. In such instances, very high gamma activity may be found at the ends of casings. Radon transported by fluids moving into the well is usually considered to be the cause of such gamma-ray anomalies.

In any gamma-ray logging system, a number of factors can affect individual readings at specific points in the well. Variations in hole diameter, mud deposition on the walls, and local fluid influx may affect the amount of radiation reaching the logging probe from the adjacent formations. Instrument errors resulting from faulty recording equipment can further degrade the accuracy with which the signals from the probe are transferred to the log record. Inadequate calibration of individual logging units within or between logging companies can and does add to the inaccuracy of the data. Finally, it is obvious that the individuals who examine the logs and record the data may, make errors in reading and tabulation. Accordingly, it is clear that no individual point should be accorded undue significance and that a statistical treatment of the data must recognize the potential for error which is inherent in this type of investigation. Nevertheless, substantial deviations from ave rage backg round values must be considered significant. Furthermore, trend surface analysis can be applied by computer techniques in such a way that the significance of individual points is reduced.

\section{ISORAD MAPS}

The five isorad contour maps (Plates II-1 through II-5, in pocket), which have been prepared from the well log data, have been plotted 
by a computer. The values and locations of the individual data points are also plotted on each map. The map contouring program makes use of a grid system consisting of 60 vertical columns and 50 horizontal rows. The numerical value of each of these $3,000 \mathrm{grid}$ points is calculated from the eight nearest surrounding data points. In making this calculation, the computer weights the value of the eight data points in inverse proportion to their distance from the grid point. For this reason data points frequently show somewhat different values than do immediately adjacent contour lines.

After the grid point values have been calculated, the contours are plotted automatically using a three-point smoothing function. In effect, this permits three additional points to be calculated between the individual grid points and helps to prevent excessively sharp curvature of the contour lines.

The data points shown on each of the maps (Plates $\amalg-1$ through II-4, in pocket) we re evaluated statistically to determine the anomalies that are indicated by shading. Histograms were prepared and the data were plotted on probability paper to determine the nature of the distributions. Figures II- 1 and II-2 show the probability plots for the average Morrison and Dakota distributions respectively. Each consists of two linear segments showing the background distribution to be normal and indicating a grouping of anomalous values in the high counting rate region. Figure II-3 shows the histog rams from which these plots were constructed. Table II-l contains the values for the means and standard deviations for the Dakota and Morrison average values and also for values at the top and bottom of the Dakota. Values of the mean plus one, two and three multiples of the standard deviation were calculated to determine anomalous levels in the data. For example, with normally dis tributed data for a single-point anomaly equal to the mean plus three multiples of the standard deviation, the probability that a single position value is due to random variation is approximately 0.0013 or about one chance in 768 . 


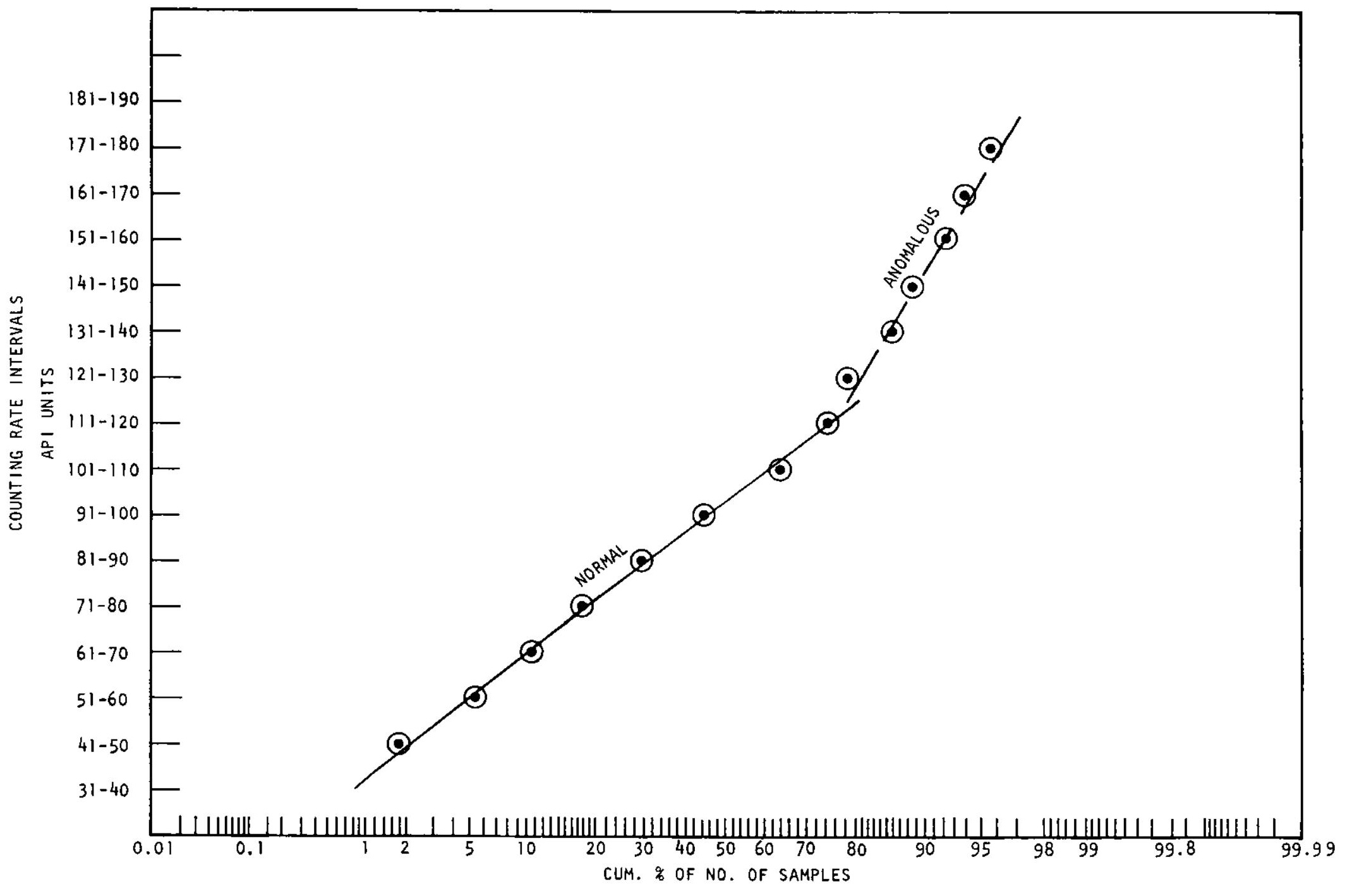

Figure II-1. Probability Plot for Morrison Fm. Average Values 


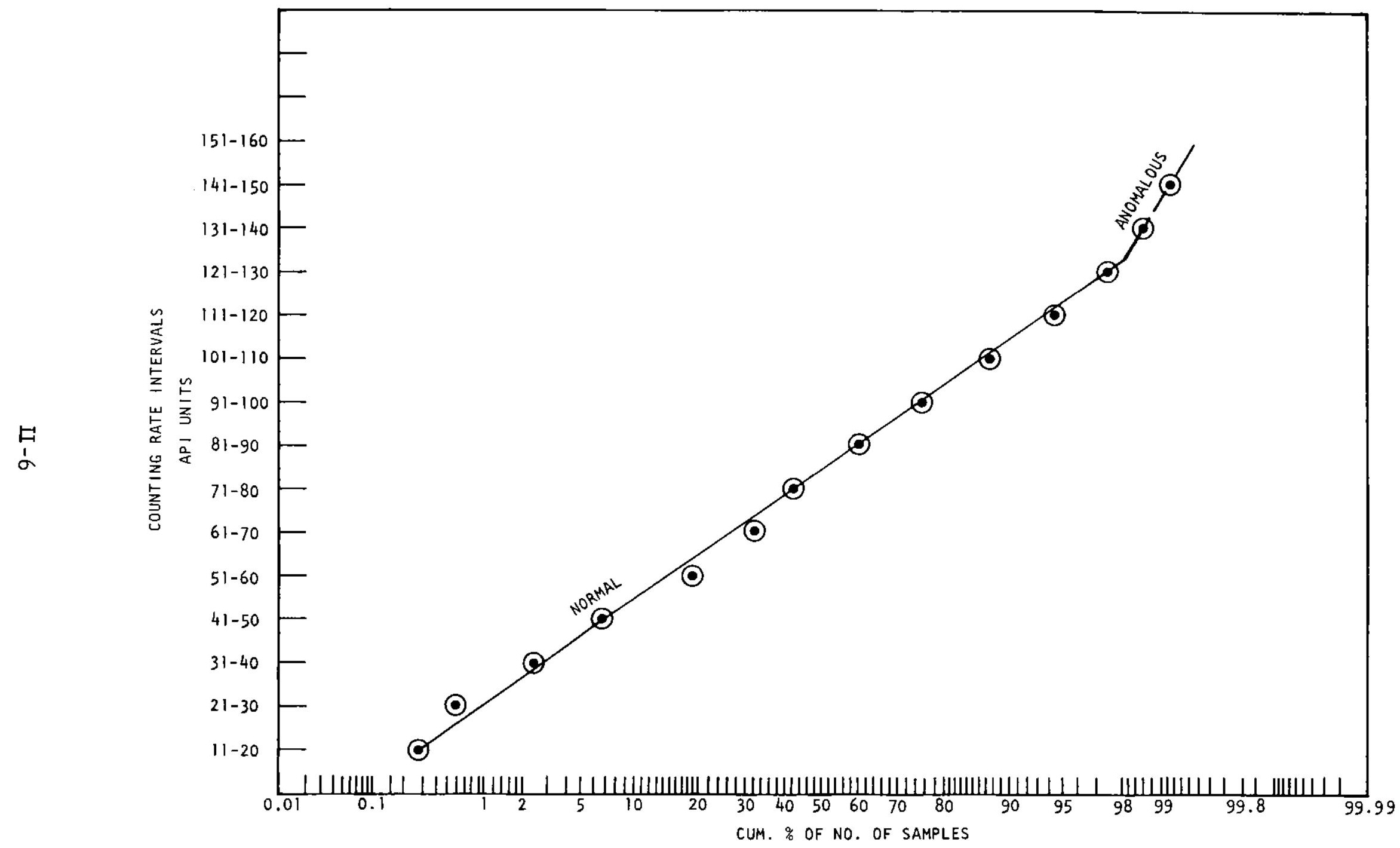

Figure II-2. Probability Plot for Dakota Fm. Average Values 


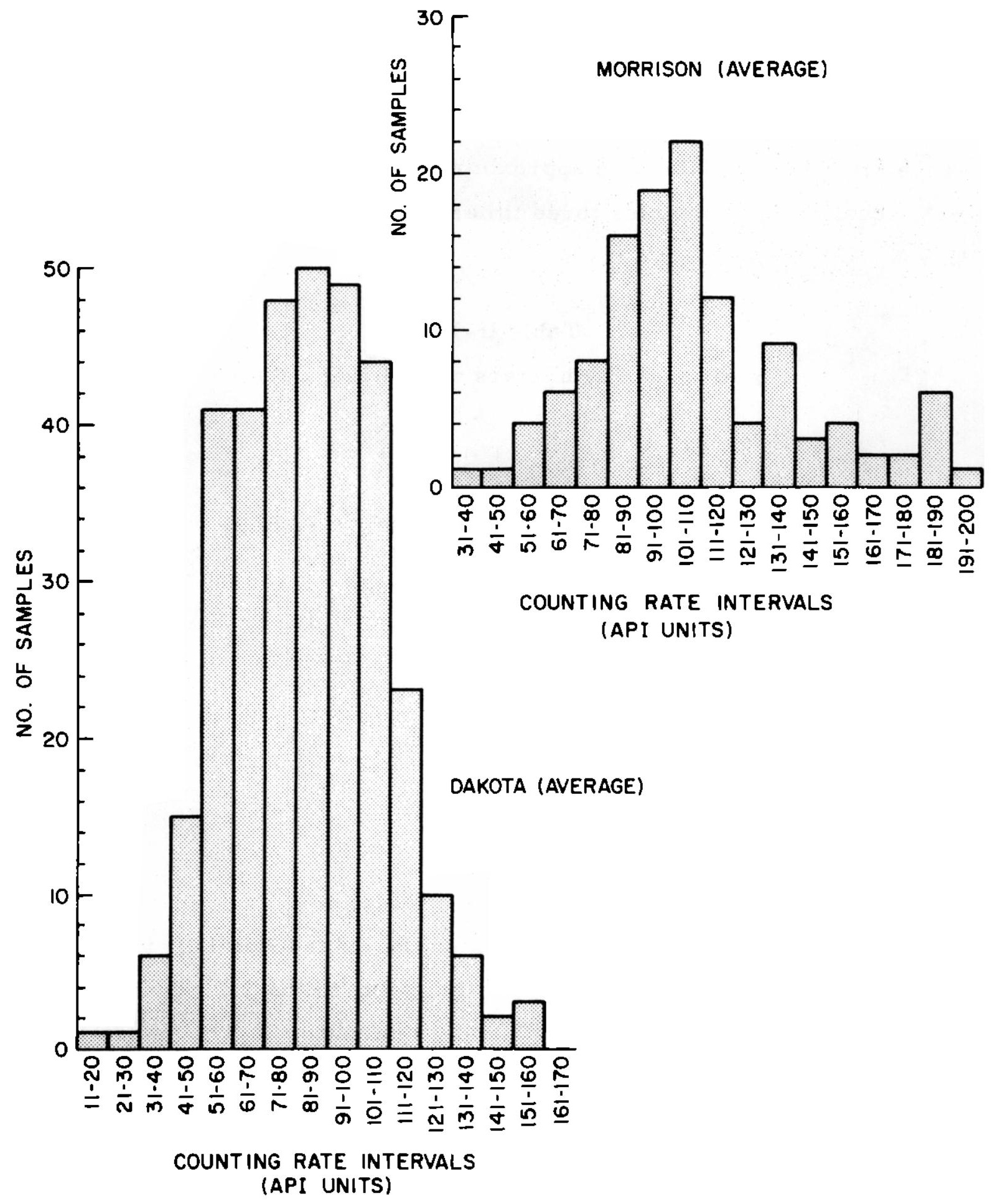

Figure II-3. Histograms 
For a value of the mean plus two standard deviations, the equivalent probability is 0.0228 or one chance in 44 ; and for a value of the mean plus one standard deviation, it is about one chance in 6. It is less probable to find groups of anomalous points caused by random variations, and statistical theory tells us that 2 adjacent high values which exceed the mean plus 1.9 times the standard deviation a re approximately equivalent to a single value anomaly equal to the mean plus three times the standard deviation (see Table II -2) .

Table II- 1

\section{Statistical Parameters - Well Log Data}

\begin{tabular}{|c|c|c|c|c|c|c|}
\hline \multirow{2}{*}{$\underset{\text { Unit }}{\text { Stratigraphic }}$} & \multicolumn{6}{|c|}{ (Values in API Units)* } \\
\hline & $\begin{array}{l}\text { Mean } \\
\text { Counting } \\
\text { Rate (M) }\end{array}$ & $\begin{array}{l}\text { Standard } \\
\text { Deviation } \\
\text { (SD) }\end{array}$ & $M+1 S D$ & $M+2 S D$ & $M+3 S D$ & $\begin{array}{l}\text { No. of } \\
\text { Samples }\end{array}$ \\
\hline Morrison (average) & $\begin{array}{c}106 . \\
(\sim 18 \mathrm{ppn} \mathrm{eU})\end{array}$ & 32.6 & 139. & 172. & 204. & 114 \\
\hline Dakota (average) & $\frac{83}{(\sim 14 \mathrm{ppm} \mathrm{eU})}$ & 23.7 & 107. & 131 & 154. & 338 \\
\hline Dakota (top) & $\begin{array}{c}87 \\
(\sim 15 \mathrm{ppm} \text { eU })\end{array}$ & 29.7 & 116 & 146. & 176. & 335 \\
\hline Dakota (bottom) & $\begin{array}{c}89 \\
(\sim 15 \mathrm{ppm} \text { eU })\end{array}$ & 33.7 & 123. & 156. & 190. & 322 \\
\hline
\end{tabular}

*100 API units are equivalent approximately to $17 \mathrm{ppm}$ eU.

The shaded anomaly levels on the maps (Plates II- 1 through II-4) were chosen as the nearest contour line value to the mean plus one standard deviation and the mean plus two standard deviations. The "more significant" anomalies (heavy dashed outlines) were picked on the basis of size of the included values and the number of points determining the anomaly. Only those exceeding the limiting probability of $1: 768$ were designated as "more significant." 
Table II-2

Single - and Multiple-Point Probabilities

\section{Single Point}

Value of Point
Probability That a Single Point Anomaly Is Due to $\mathrm{R}$ andom Variation* $\geq$ Mean +1 Std. Dev.

$\geq$ Mean +2 Std. Dev.

$\geq$ Mean +3 Std. Dev.
0.159

0.23

0.0013
$1: 6$

$1: 44$

$1: 768$

\section{Multiple Point (from Elkins, 1940)}

No. of Points Supporting Anomaly

1

2

3

4

5

6

7
Minimum Deviation from the Mean for a Limiting Probability of 1:768

$$
\begin{aligned}
& +3 \times \text { std. dev. } \\
& +1.8 \times \text { std. dev. } \\
& +1.2 \times \text { std. dev. } \\
& +0.9 \times \text { std. dev. } \\
& +0.6 \times \text { std. dev. } \\
& +0.4 \times \text { st. dev. } \\
& +0.3 \times \text { std. dev. }
\end{aligned}
$$

*Probabilities determined by the ratio of the area below the standard normal distribution curve above the point value to the total area under the distribution curve.

\section{INTERPRETATION OF ISORAD MAPS}

The values shown on the isorad maps are in terms of gross gamma-ray activities which can originate from the thorium decay series or potassium -40 as well as from the uranium decay series so that caution must be used in interpretation. Minor regional gamma-ray activity variations could be due to changes in the thorium content of the heavy mineral fraction of the formations or to changes in the potassium concentration which will vary with the clay content or a rkosic nature of the formation. Any major 
increases in gamma activity are probably due to variations in the uranium content but should be checked by examination of other types of logs, core examination, and if at all possible, by sampling and uranium analysis before drawing any final conclusions.

Examination of Plate II-1 (in pocket) shows that the re are three more significant anomalies in the Morrison Formation in Norton, Graham, She ridan, and Wallace counties.

Plate II-2, the average values for the Dakota, shows three more significant anomalies; the largest covering much of Wallace, Wichita, Scott, Kearny, and Hamilton counties. The next largest covers parts of Gove, Logan, and Ness counties; and the third is located in Norton Co. Superposition of Plate II-2 on Plate II-1 shows that anomalies in Wallace and Norton counties are found in both the Dakota and the Morrison.

Plate II-3, values for the top portion only of the Dakota Formation, also shows four more significant anomalies spread over parts of Sherman, Thomas, Wallace, Logan, Greeley, Wichita, Scott, Hamilton, Kearny, Sheridan, Graham, Gove, Trego, and Ness counties. The high values in Ford and Cloud counties are single-point anomalies and are not considered to be in the "more significant" classification.

Superposition of Plates II-1, II-3, and $\amalg-4$ shows that the strongest and most "reinforced" anomalies are in Norton, Wallace, Logan, Gove, Greeley, Hamilton, Kearny, and Scott counties. Landis (1960) found large amounts of uranium in surface water and groundwater samples collected in the valley of the Smoky Hill River in Wallace, Logan, and Gove counties. It is tentatively concluded that these areas are probably relatively en riched in uranium and may indicate potential uraniferous provinces. This must be confirmed by drilling and sampling the subsurface formations for specific uranium analyses. 


\section{E. DISTRIBUTION OF DAKOTA HIGHEST VALUES}

Plate II-5 (in pocket) shows the highest values found in any part of the gamma-ray well logs in the Dakota Formation. The contoured data has been shaded to show the distribution of the highest of the se values. The levels for shading were chosen to bring out the shape of the surface and are not based on a statistical analysis of the data.

As would be expected, the groupings of very high values reflect generally the uraniferous provinces defined on Plates II- 1 through II -4 with additional minor areas appearing in Rawlins, Decatur, Graham, Osborne, Ellis, and Grant counties. These represent high readings not reflected in the upper or lower parts of the Dakota and not sufficiently strong to be seen as anomalies in the average values for the Dakota. They may represent additional areas of uranium enrichment and are included here for completeness.

\section{F. STRATIGRAPHIC SECTIONS}

Each of the stratigraphic sections which appear in Figures II-4 through II-8 were prepared as a composite from several well logs in the county and state listed (see Figure I-1 for index to localities). They are intended only as graphic representations of the average stratigraphic columns which are present in these counties. The section from Union County, New Mexico was prepared from information given by Baldwin and Muehlberger (1959).

In conducting this research, special attention has been paid to Finch's (1967) list of stratigraphic units known to produce uranium. The Dakota and Morrison formations were selected for the subsurface study in western Kansas largely on this basis, together with the fact that their lithologies are similar to those in areas where they a re known to produce, and they are distinctive and easily recognized in the subsurface. An attempt 


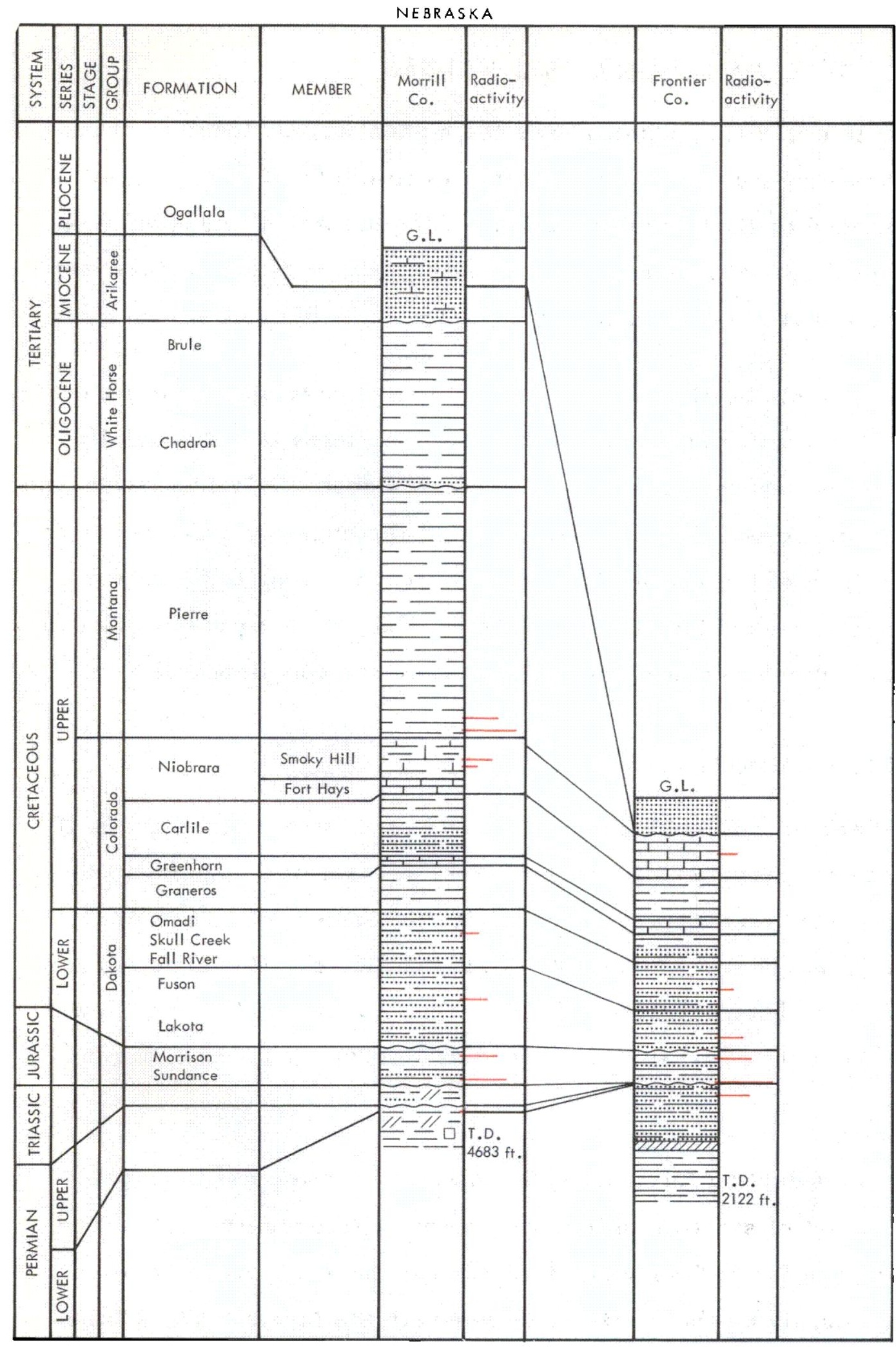

EXPLANATION

-

$E-$

EII

Sandstone

\begin{tabular}{|c|c|}
$\Delta \Delta$ & Chert
\end{tabular}

用 Salt

E11

E.-. Siltstone

$=-1$

I Limestone

ris

\begin{tabular}{lll}
\hline Dalomite \\
\hline$y$ D
\end{tabular}

Calcareous

= shale

Sandy shale or

shaly sand

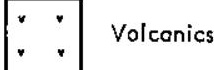

G.L. : ground level

T.D. : total depth

T.T. : toral thickness

Figure II-4. Stratigraphic Section- - Nebraska 


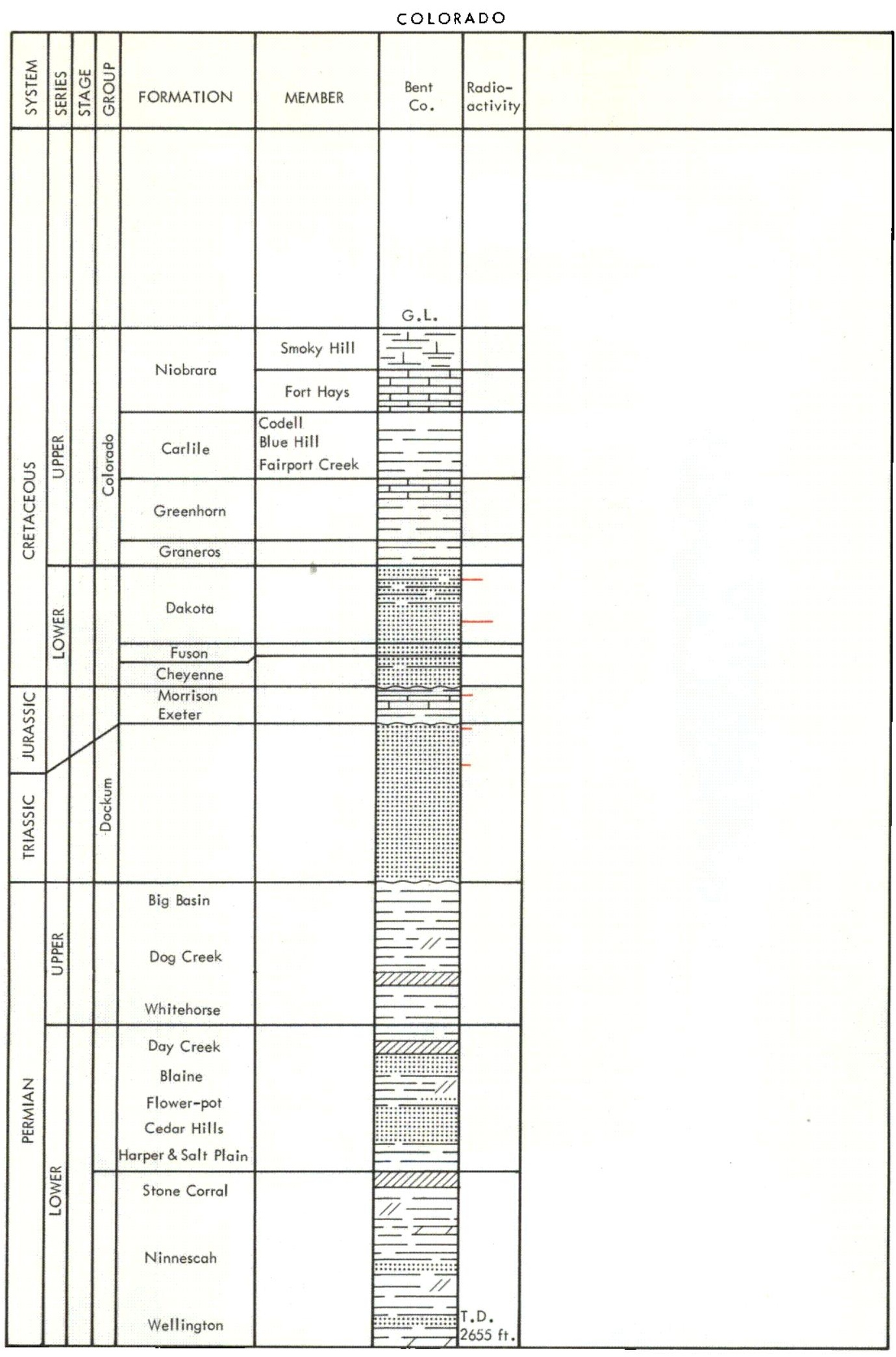

EXPLANATION

E- $\Rightarrow$ Shate

-

Sondstone

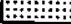

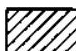

Anhydrite

$\Delta \Delta \quad$ Chert

Solt

世車

E-A Siltstone

-

Limestone

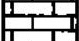

Dolomite

7

DI- Calcareous

三1二

Sondy shale or

……....... shaly sand

$\begin{array}{rr}. & v \\ . & \text { Volcanics }\end{array}$

ry

G.L. : ground level

T.D. : total depth

T.T. : total thickness

Figure II-5. Stratig raphic Section - Colorado 


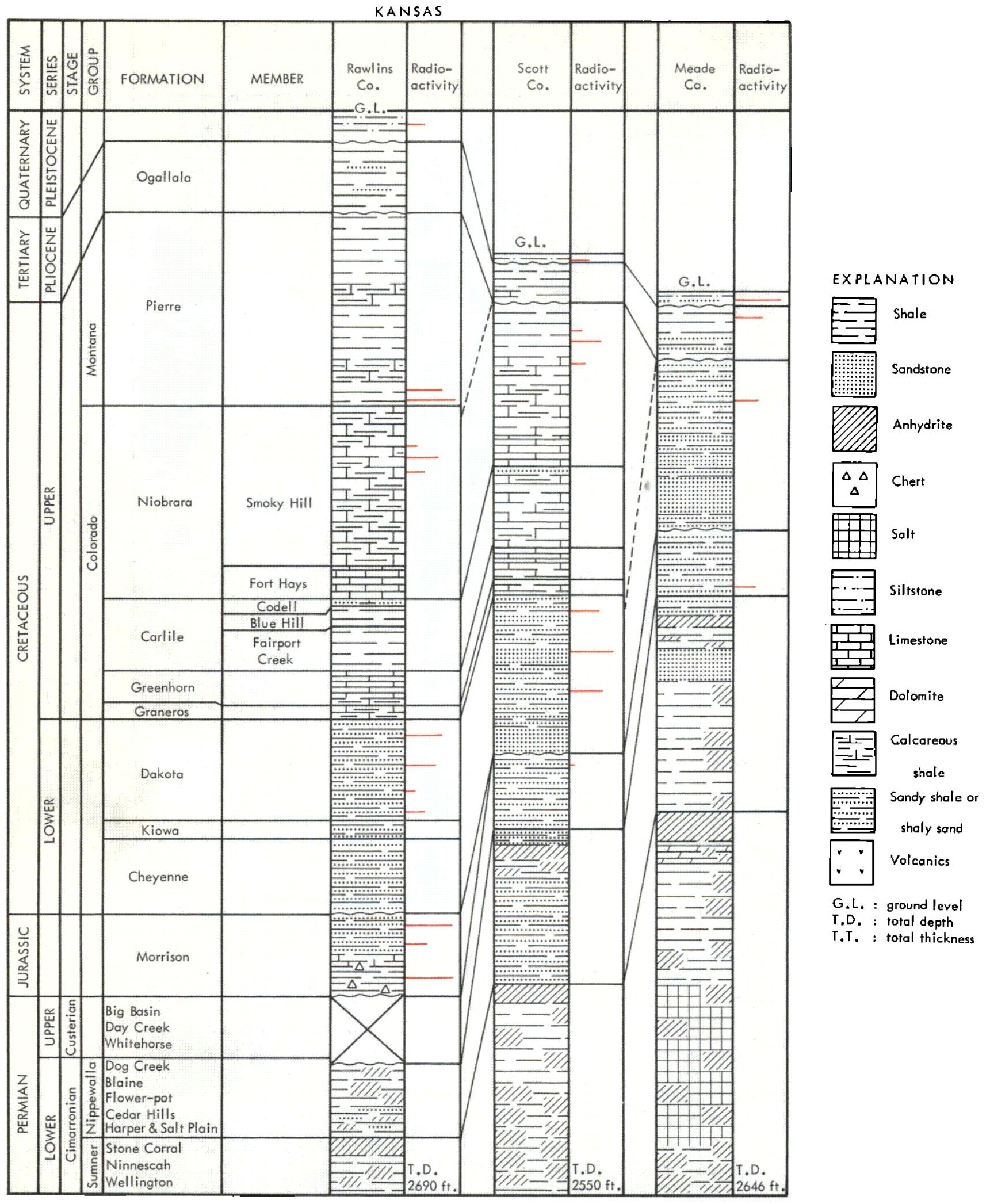

Figure II-6. Stratigraphic Section - Kansas 
NEW MEXICO

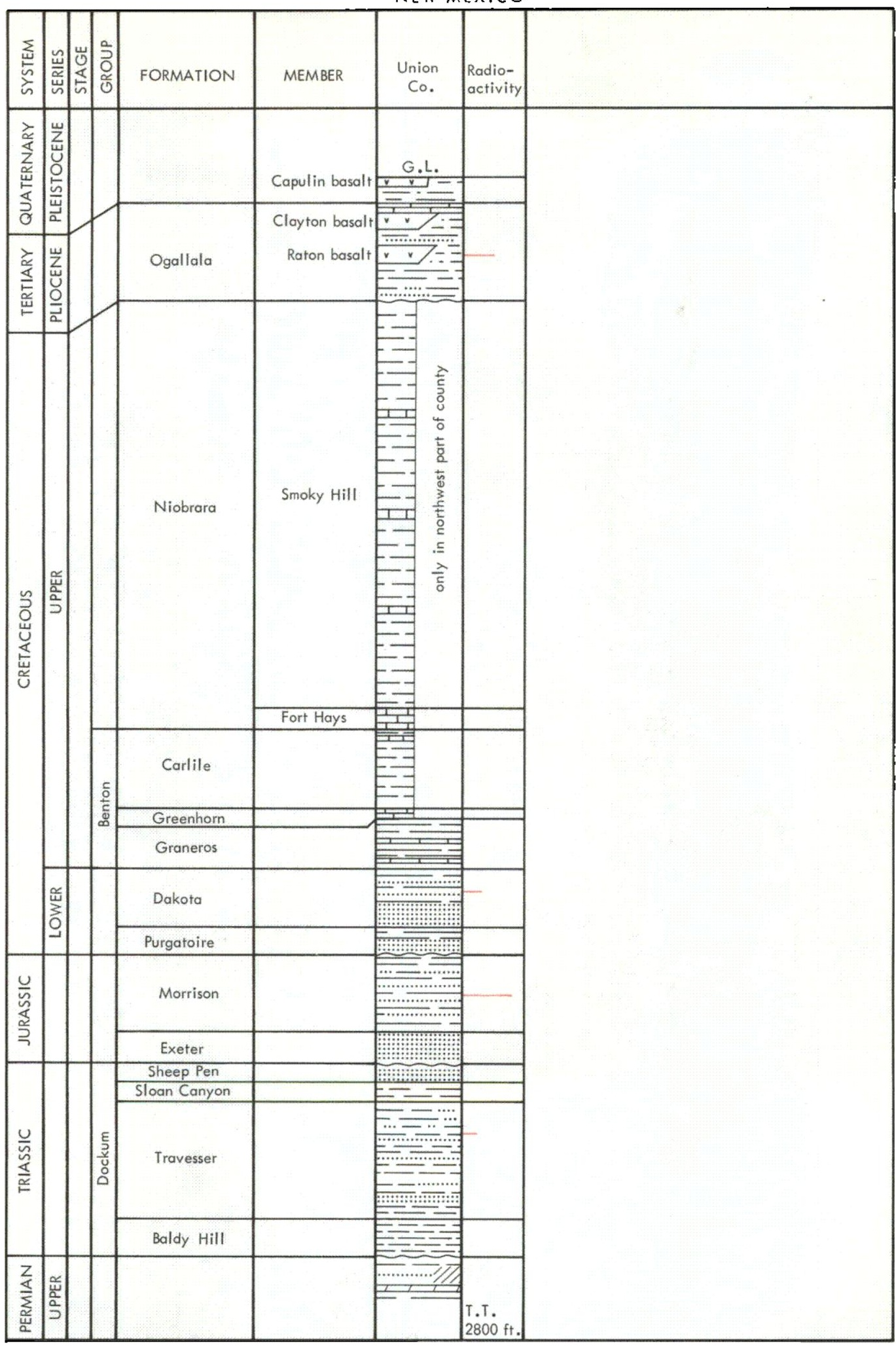

EXPLANATION

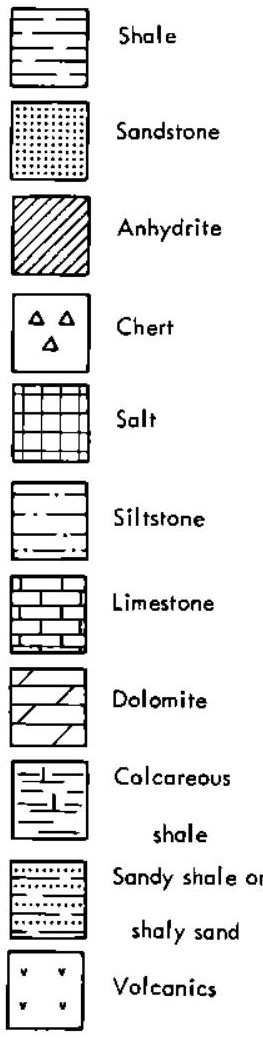

G.L. : ground level

T.D. : total depth

T.T. : total thickness

Figure II-7. Stratig raphic Section - New Mexico 


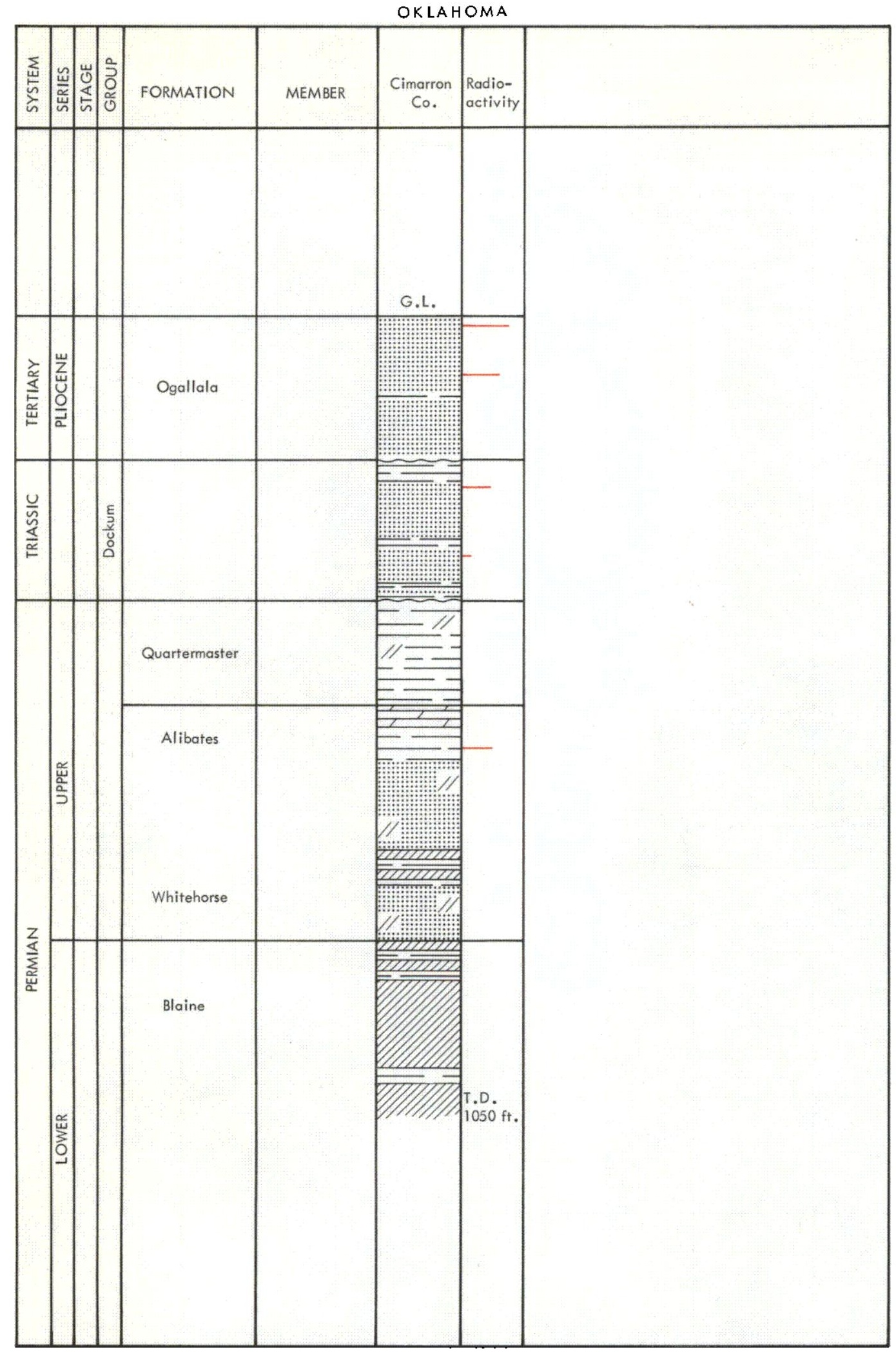

EXPLANATION

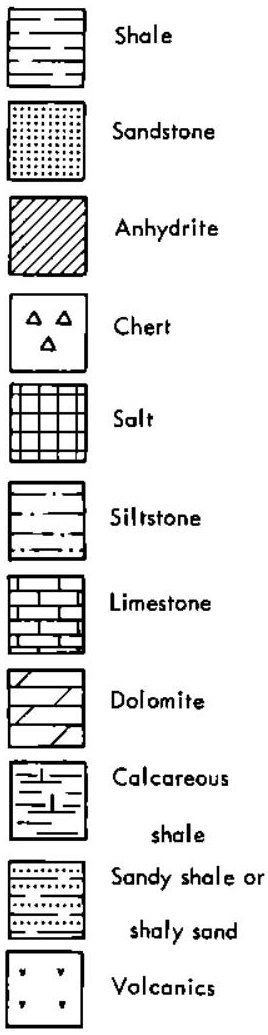

G.L. : ground level

T.D. : toral depth

T.T. : total thickness

Figure II-8. Stratigraphic Section - Oklahoma 
was made to examine all of the equivalents of producing formations which occur in the study area either in outcrop or in the subsurface. The list included:

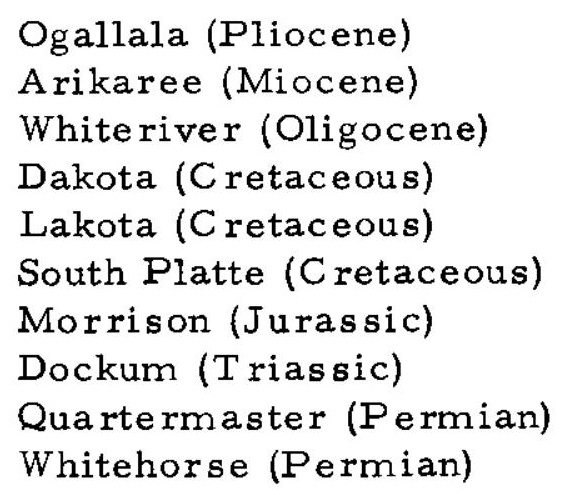

Among the total formations examined, anomalously high radioactivity was found in all except the Quartermaster. The distribution of anomalous radioactivity in the stratigraphic units is best seen in the stratigraphic sections which appear in Figures II-4 through II-8.

\section{G. NEAR -SURF ACE GAMMA-RAY WELL LOG ANOMALIES}

In order to establish any possible correlation between the subsurface anomalies in the Dakota and Morrison and near-surface radioactivity, a survey of all of the well logs was made to determine whether nearsurface rocks showed similar high radiation levels. In this study, all wells which show gamma-ray intensities of 100 API units or more, ( $17 \mathrm{ppm} \mathrm{eU})$ within 100 feet of the surface are indicated with heavy dots on the map in Plate II-6. Since most wells are cased in the upper 100 feet, the true anomaly would actually be somewhat higher than that recorded in an open hole below the surface pipe. Although no statistical significance can be attached to the selection of 100 API units as a limiting value, it is roughly double the average radiation level in the upper 100 feet of the total number of wells examined. 
Attention should be called to the fact that the data from which this map is produced is not differentiated on the basis of the lithologic character or geologic age of the beds penetrated. Along the eastern and southern border some of the high values are produced by the Dakota sandstone which is exposed at the surface. Most of the wells north and west of this Dakota outcrop band are started in sediments of Tertiary age; however, and the anomalous values are probably within these sediments.

A rough correlation is evident between these shallow subsurface anomalies and the deeper subsurface uraniferous provinces in the Dakota and Morrison formations of western Kansas. Counties that contain more than one near-surface high value which is unrelated spatially to the underlying anomalies are: Rawlins, Decator, Graham, Osborne, Ellsworth, and Grant. 
SECTION III

REGIONAL LANDSAT (ERTS) LINEAMENT STUDY

\section{A. GENERAL}

Geomorphic lineaments derived from imagery obtained by the Earth Resources Technology Satellite (ERTS-1; now termed LANDSAT-1) are used in this analysis as indication of regional structure. Saunders, Thomas et al. (1973) observed that uranium mining districts in the Colorado Plateau appeared to be "loosely associated" with (i.e., scattered along) regional lineaments which are apparent on ERTS-1 imagery as linear arrangements of topographic features such as linear stream segments or tonal contrasts. A similar relationship was noted in Wyoming (Texas Instruments Incorporated, 1974). These lineaments are most easily seen on 1:1,000,000 scale imagery, and on the basis of much recent study, are interpreted to represent major planes of weakness in the earth's crust. It is believed that many of these "geosutures" or shear zones have been present since the Precambrian and were active at various times throughout the earth's history, exerting influences on sedimentation processes as well as folding, faulting and the emplacement of intrusives and associated lode mine ralization (Saunders, Thomas et al., 1973; Saunders, 1974; Freden et al., 1974). Their spatial association with uranium deposits is believed to be caused by the lineaments functioning as vertical transmission paths for mineralized groundwaters. The concentrated zone of high angle faults and joints controlling stream drainage and other geomorphic effects to make the lineaments visible provides an easy route for downward percolation of waters from a source bed to a potential host rock where horizontal migration to a proper geochemical environment could allow an ore body to form (Saunders, 1974). These zones of faults and joints may be as much as several miles wide. 
The general association of Laramide lode mineralization (including uranium veins) in the western U.S. with northeast trending vein systems and shear zones has been pointed out by several authors (Saunders, Thomas et al., 1973; Landwehr, 1967; Stokes, 1968; and Tweto and Sims, 1963). Many mineral deposits (again including uranium veins) have been observed to occur along the well-known Texas and Lewis and Clark lineaments (Wertz, 1970; Hobbs and Fryklund, 1968), both of which strike generally west-northwest.

Even though the exact mechanisms of possible lineament control on mineral deposition are not yet well understood, it appears reasonable to use the observed empirical relationships as one of the guides in future prospecting operations.

\section{B. PREPARATION OF REGIONAL LINEAMENT MAPS}

The regional lineaments shown in Plates $\amalg-1$ through $\amalg-6$, and III- 1 and III-2 (in pocket) and Figure IV-1 were mapped from IANDSAT (ERTS) mosaics obtained from the USDA Soil Conservation Service, Hyatts ville, Md., using the techniques developed by Saunders, Thomas et al. (1973) and Saunders (1974). Separate mosaics for spectral bands $5(0.6$ to 0.7 micrometers) and $7(0.8$ to $1.1 \mathrm{micrometers)}$ were prepared by the Soil Conservation Service using imagery collected during the period from July 23 to October 31,1972 . Both were used in annotating the regional lineaments. Experience has shown that the linear drainage features generally are more easily annotated on the band 7 imagery, and tonal features are more easily discerned on band 5 imagery. For annotation the mosaic was placed on a light table and backlighted in a dimly lighted room. The linear drainage and tonal features were recorded on a clear mylar film overlay using wax pencils or drafting tape. The band $7(1: 1,000,000$ scale) mosaic was used first, followed by the band 5 mosaic. The lineaments were then enlarged to overlay 
on 1:500,000-scale mosaics where the annotation was completed. Relatively strong reliance was placed on major drainage features in locating these lineaments. Linear arrangements of tonal features supplemented the drainage in def ining them. Names have been assigned based on nearby mapped features.

\section{RELATIONSHIP OF LINEAMENTS TO WELL LOG DATA}

Examination of Plates $I I-1$ through II-6 shows that nearly all the high gamma-ray log anomalies lie on or adjacent to the regional geomorphic lineaments. This is compatible with their postulated function as preferred vertical migration paths for mineralized groundwaters.

The more significant anomalies in the Morrison Formation (P1ate II-1) appear to be related to the Goose Cr., Prairie Dog Cr., Holly, Lenora, and Sand Cr. lineaments. Even the minor anomalies appear to be line ament-cont rolled.

In Plate II-2, the more significant anomalies in the average values for the Dakota Formation appear to be related also to the Goose Cr., Prairie Dog Cr., and Holly lineaments and additionally to the Gove, Wild Horse, Lamar, Modoc, and Kirwin lineaments.

The more significant anomalies at the top of the Dakota (Plate II-3) appear to be related to the Goose Cr., Prairie Dog Cr., Gove, Lamar, Modoc, and Kirwin lineaments with no apparent association with the Holly and Wild Horse lineaments. Three of the less prominent anomalies are closely alligned with the Cedar Bluff lineament.

The bottom part of the Dakota (Plate II-4) shows apparent control of the anomaly locations by the Prairie Dog Cr., Goose Cr., Gove, Wild Horse, Lamar, Holly, Modoc, Friend, and Kirwin lineaments. Most of the less prominent anomalies also show apparent relationship to the regional line aments. 
In Plate II-5, even the additional minor Dakota highs not reflected in Plates II-2 through II-4 appear to be related to the regional lineaments also.

Examination of Plate II-6 shows that more than $75 \%$ of the near-surface high values are on or near the regional lineaments.

Overall, the data lead to the conclusion that the gamma-ray anomalies appear to be controlled by fluid movements in the lineament fracture zones. This type of behavior is more consistent with the geochemistry of uranium and its daughters than with the expected behavior of potassium or thorium, and is taken as support for the tentative conclusion that the anomalies are largely due to variations in uranium content. It should be noted the lineaments may have controlled paleostream channels as well as modern drainage and could be the locations for place $r$-type heavy mineral concentrations. Those placers containing significant quantities of thorium are usually found much nearer crystalline source areas rocks than the western Kansas region is to its postulated sources. On this basis it is doubted that any significant contribution to the gamma-ray logs are from placer thorium. This must, of course, be confirmed by sampling and analysis.

In this map area the only lineaments which have shown apparent relationships to uranium deposits outside the study area are the Apache, San Juan, and Elk Mountains - Apishapa. The San Juan and E1k Mountains Apishapa lineaments are at the very edges of the well log study area and are not adequately sampled. The Apache is adequately sampled and shows a possible relationship to three of the less significant anomalies only.

The data tend to negate the hypothesis that certain lineaments may be more favorable for uranium than others over large distances. It appears more likely that any zone of concentrated fracturing or jointing may control solution movement, but the formation of an anomalous concentration 
of uranium is primarily dependent on such factors as the presence of a suitable source and host rock from both the geochemical and structural viewpoints.

\section{POTENTIAL APPLICATION OF LINEAMENTS IN URANIUM RECONNAIS- SANCE}

\section{Lineament Detection by Surface Gamma-Ray Spectrometry}

At the beginning of this study is was hoped that field traversing, across the lineaments with a car-borne gamma-ray spectrometer might reveal their presence in terms of slightly higher counting rates. This is reasonable because radon can be expected to migrate up fracture or fault zones to yield anomalous gamma activities from its daughters. Several traverses were made across lineaments (see Section IV) and no significant differences we re detected in Bi-214 activity. Because of the limited sensitivity of the gamma-ray spectrometer and wet-weather limitation on off-road traversing, no definite conclusions can be drawn from these data as to the detectability of lineaments by this method. It is concluded that a much more sensitive spectrometer unit should be used, and that the search should be made using airborne equipment to obtain better sampling of the surface activity than is possible when sensing at the surface.

The near-surface gamma-ray log data imply that surface detection should be possible, and it is suggested that some of the se anomalies may be due to upward migration of radon in the fracture zones. If this be the case, then emanometer surveys of shallow soil gases may provide a way to detect them.

2. Regional Geomorphic Lineament Map of the Central Great Plains

$$
\text { Originally it was planned to present the regional lineaments on }
$$
a base map showing the outcrops of potentially favorable host rocks in the 
study area. This would have involved redrafting (with its attendant errors) of data from the state geologic maps, and it was decided that a better approach would be to provide the lineament data at 1:500,000 scale as prints which can be used as overlays on the published state geologic maps covering the area by employing a light table. Plates III-1 and III-2 (in pocket) cover the northern and southern parts, respectively, of the study area. These are mapped on an Albers Equal Area projection and must be shifted degree by degree to match closely the state geologic maps at the same scale. Those lineaments which have shown apparent relationship to known economic uranium deposits outside the study area are indicated by hachuring (Saunders, 1974). As indicated above, this may not be particularly significant, and probably all lineaments can act as vertical migration paths with the formation of a stratiform deposit dependent primarily on other conditions. If these conditions exist, it is much more likely that deposits will be formed on or near the lineaments than in the centers of the "blocks" between the lineaments. Inspection of Figure IV-1 shows that all of the known uranium occur rences in the study area (see Section I. C) are found on or adjacent to regional lineaments. Thus, it may be concluded that the lineaments are useful as one of the guides in reconnaissance prospecting to provide focus for the application of other methods where they are more likely to be successful.

It is suggested that Plates $\amalg I-1$ and III-2 be used by other investigators studying the uranium content of ground and surface waters, high- . sensitivity airborne gamma-ray spectrometer survey results, etc., in this region to test for possible relationships between their data and the lineaments. The lineaments also should be useful in any further studies of gamma-ray well logs in this or other areas.

\section{E. THE INF LUEN CE OF UNDER LYING SALT DEPOSITS ON THE DEPOSI- TION OF URANIUM}

The presence of thick, stratified salt deposits in the subsurface over about $50 \%$ of the total study area (Figure III-1) is of major 
significance in determining the possible origin of any uranium deposits that might be present. The isorad maps of the Dakota and Morrison formations indicate that the re is some relationship between the lineament fabric in central and western Kansas and the subsurface anomalies. However, it is clear that this relationship cannot have developed through the upward migration of uranium-bearing solutions from the crystalline basement, along fractures associated with lineaments. Salt beds are generally considered to be impermeable because of their plastic properties, and it is this characteristic which has made such deposits of major interest as sites for the disposal of highlevel radioactive wastes. Extensive experimental and theoretical studies have confirmed the effectiveness of salt in horizontal beds in preventing vertical movement of groundwater (Bradshaw and McClain, 1971). Fractures cannot remain open because of plastic flow, thus movement of uranium-bearing solutions along fracture channels which might exist above or below the salt is effectively prevented across the salt body itself. In this sense, the salt body acts as an impermeable barrier, which serves to isolate the overlying rocks from the stratigraphic section beneath it. Fracture systems possibly associated with lineaments could remain open above the salt because of the brittle nature of most sedimentary rocks. These fractures could permit downward circulation of groundwater from overlying beds from which uranium is being leached.

In view of the se facts, it appears that any accumulation of uranium in sediments above a salt sequence must either have been deposited penecontemporaneously or by subsequent downward migration of uraniumbearing solutions. This concept is especially important in the mid-Continent area, because of the extent and thickness of salt beds of Permian age, which are distributed from Texas northward to the $C$ anadian border.

Figure III-2 shows the relationship between the areas of anomalously high radioactivity in Plates II -1 , II -3 and II -4 and the major salt 


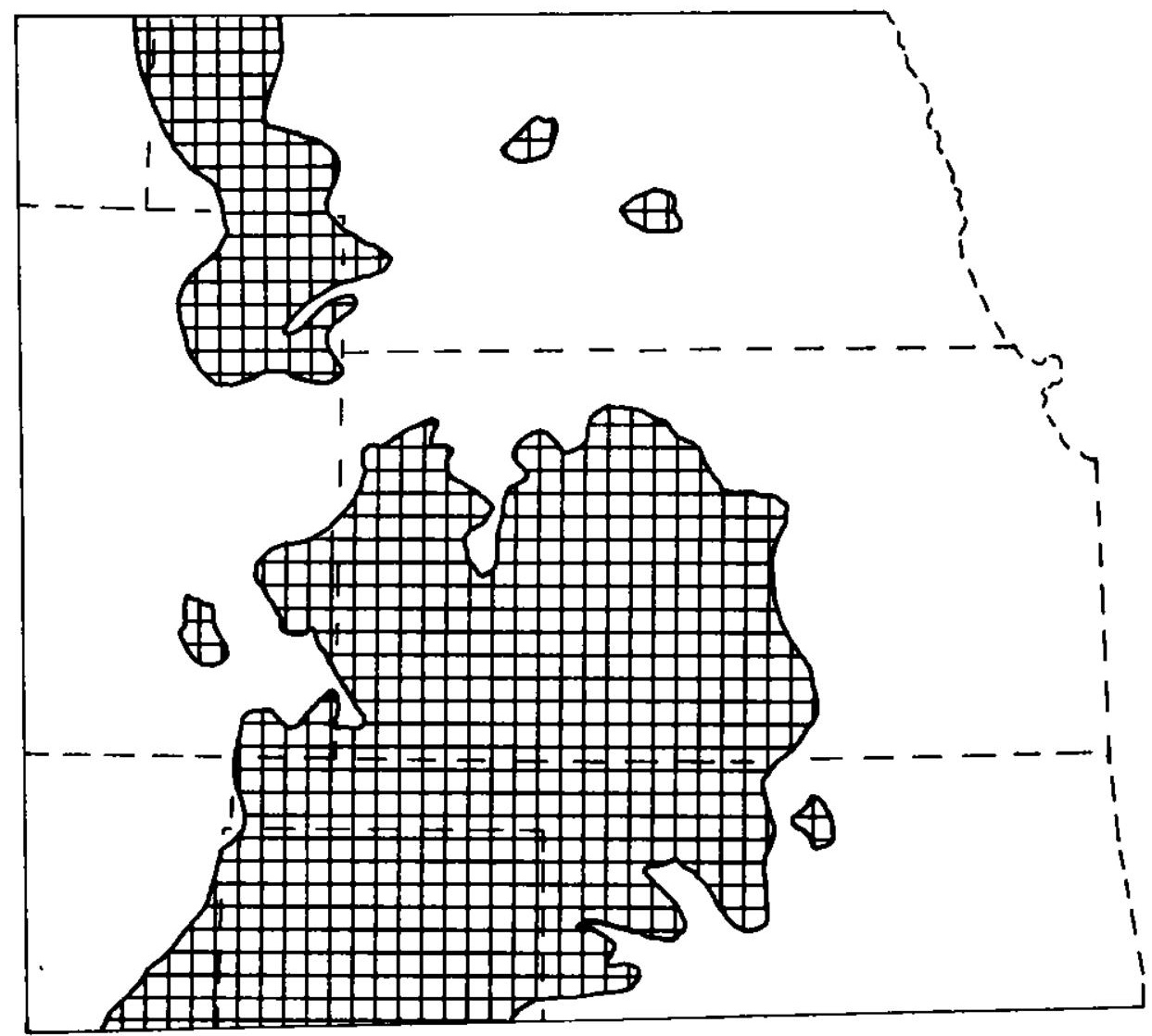

Figure III-1. Distribution of Salt of Permian Age in the Central Mid-Continent Region (after Mudge, 1967) 


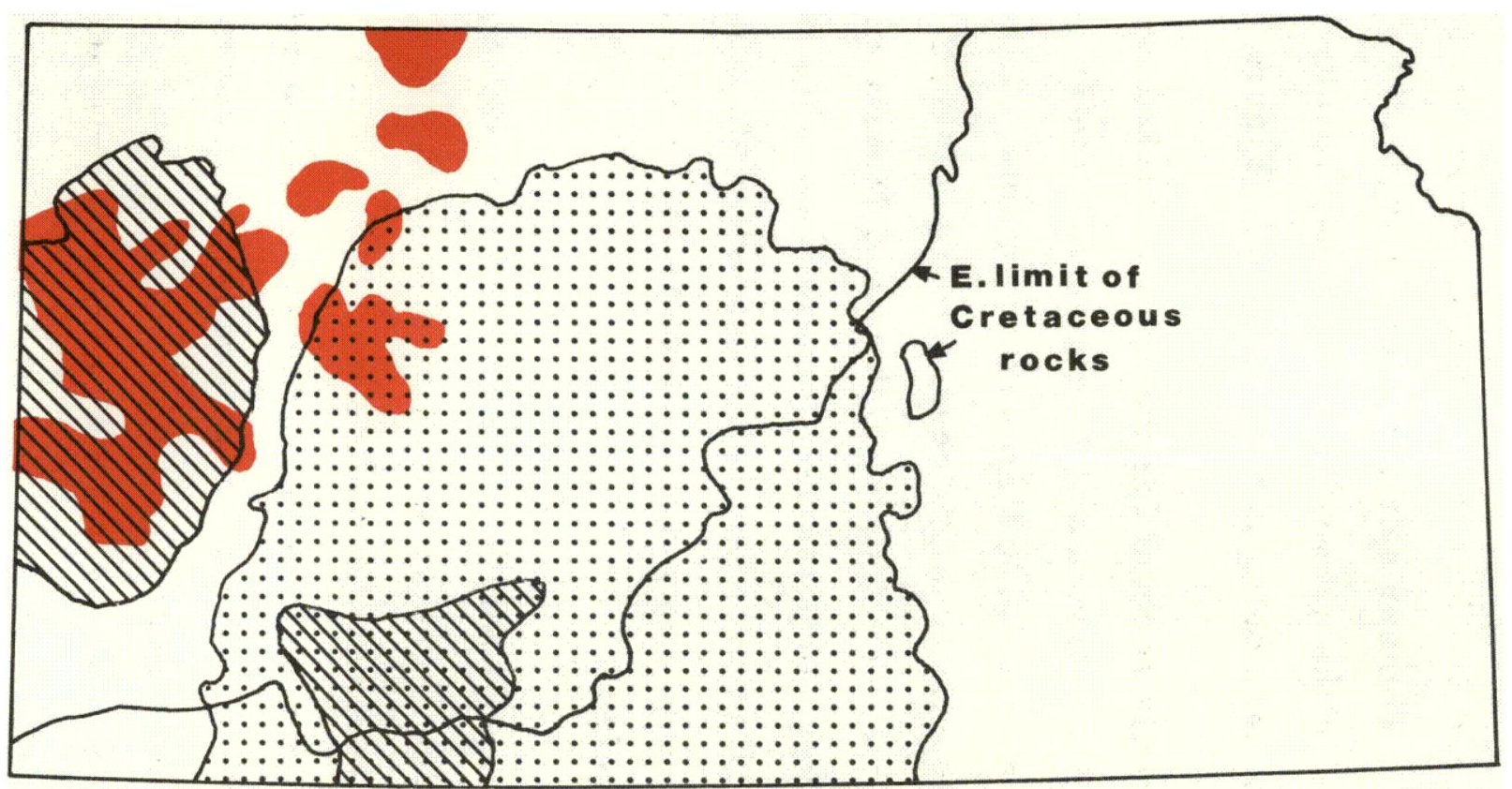

\section{Flower-pot salt}

: Hutchinsonsalt
Significant radioactivity anomalies

Figure III-2. Relationship Between Salt Bodies and Significant Radioactive Anomalies. (Limit of Wellington salt after Kulstad, 1959; 1imit of southern Flowerpot salt body after Schumaker, 1966) 
bodies of Kansas. It is clear that a very large proportion of the total area of anomalously high radioactivity overlies the salt bodies. Furthermore, it is particularly significant to note that the anomalies which occur above the western Flower-pot salt body are large contiguous areas, while those not overlying this salt body tend to be smaller and disconnected. The Flowerpot and Hutchinson salt both exceed 200 feet in thickness over most of the area covered by the salt bodies. Thinner salt deposits occur at other stratigraphic horizons in the Permian in the subsurface of Kansas, resulting in much of western and southern Kansas being underlain by salt (Figure III-1).

Several factors could account for the apparent relationship between radioactivity anomalies in the Dakota and Morrison and the existence of extensive stratified salt in the underlying Permian sediments. Theoretically, all of the anomalous radioactivity might result from potassium 40 being transported upward from the salts into the Dakota and Morrison. This obviously is not the case, however, as potassium minerals are not present in the stratified salt deposits of Kansas. The halite and anhydrite beds of Kansas are characterized by gamma-ray activity which is lower than any other part of the stratigraphic section.

The Permian salt beds might cause the development of geochemical conditions in the overlying Dakota and Morrison which would favor the accumulation of uranium. Uranium compounds tend to be soluble under oxidizing conditions, and the solubility is further increased if carbonate ions are present. Under these conditions, the uranium can form complexes with the carbonate ions and can be removed from solution only if reducing conditions are encountered. Hathaway et al. (1975) showed that groundwaters from the Ogallala Formation in southern Wallace, Greeley, Wichita, Scott, and Lane counties are basically calcium-magnesium bicarbonate in nature. Test borings made in western Kansas show that the Dakota sandstones are saturated with waters containing roughly $1,000 \mathrm{mg} / 1$, total dissolved solids. 
It appears likely that any permeable beds in the underlying Morrison are also saturated with these brines. Of particular significance is the fact that the major constituent of the Dakota waters in west central Kansas is not sodium chloride; it is instead sodium bicarbonate (K. M. Keene, Kansas Geological Survey, report in progress).

Such waters would be highly favorable as a transport medium for uranium. Solubility would be higher than in normal fresh waters, and the uranium would tend to remain stably in solution until it was transported into regions where reducing conditions might be encountered. Pyrite and disseminated carbonaceous fragments are common in both the Dakota and Morrison in the subsurface of western Kansas, and this material would provide a favorable environment for the precipitation of uranium from the dilute brines saturating the formations.

The waters in the Dakota sandstones overlying the Hutchins on salt body (Figure III-2) are much higher in sodium chloride and total dissolved solids than those over the western Flower-pot salt. Sodium chloride brines are probably less favorable as transport media for uranium in solution, and this may account in part for the fact that the large contiguous anomalies are located over the western Flower-pot salt body. 

SECTION IV:

ROAD TRAVER SES AND SURF ACE FIELD IN VESTIGATIONS

\section{A. GENERAL}

The routes of surface traverses made during this program and the location of specific surface examinations are shown in Figure IV -1 .

All road traverses and field measurements were made using a Scintrex GIS-3 gamma-ray spectrometer equipped with a 2 in. $x 2$ in. NaI ( $\mathrm{T}$ l) detector, and a scintillometer manufactured by Atomic Research Corporation. The latter instrument provides only total count.

Although road traverses are clearly of value for uranium resource evaluation studies, they are perhaps less than normally useful in the Central Great Plains area because of low relief, soil cover and related farming practices, together with poor outcrops, which combine to make this type of reconnaissance of limited value. In most instances material used in road surfacing contributes more to radiation levels measured from vehicles than does the area of interest adjacent to the road. Extensive tillage of the soil in fields along roads conceivably may result in leaching and partial removal of low-level surface uranium concentrations. If this occurs, the preexisting surface anomaly may be reduced or virtually eliminated and may become undetectable by vehicle traverses on unimproved roads or even on foot.

Substantial portions of the Central Great Plains area are covered by wind-blown sand deposits. Large presently inactive dune fields exist in parts of Kansas, Colorado, and Nebraska as well as in Texas and Oklahoma panhandles. Small areas of active dunes are also present mostly as remnants of the much more extensive dune development which occurred during the dust bowl period in the early 1930's. The existence of these recent eolean deposits 


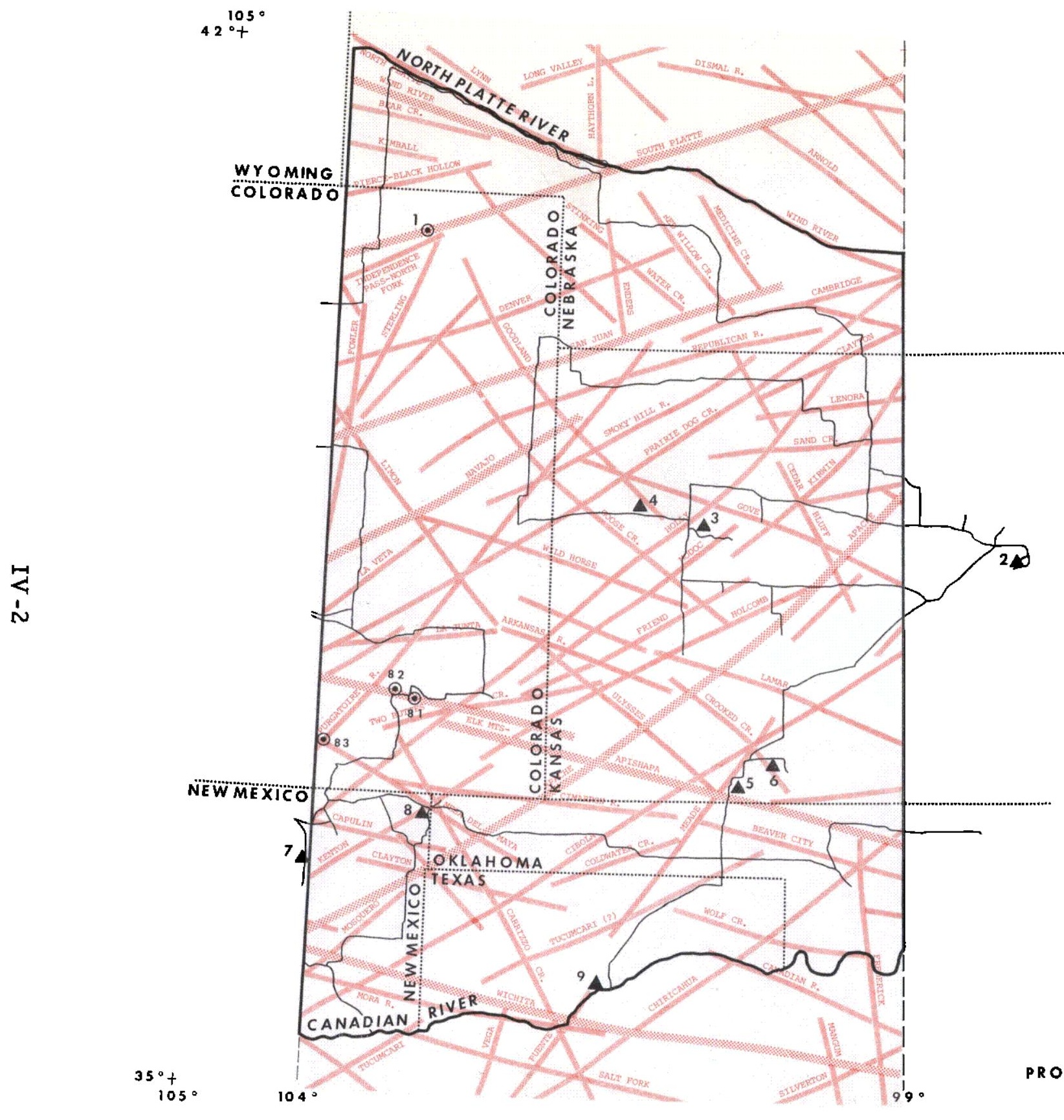

$96^{\circ}$
$+42^{\circ}$

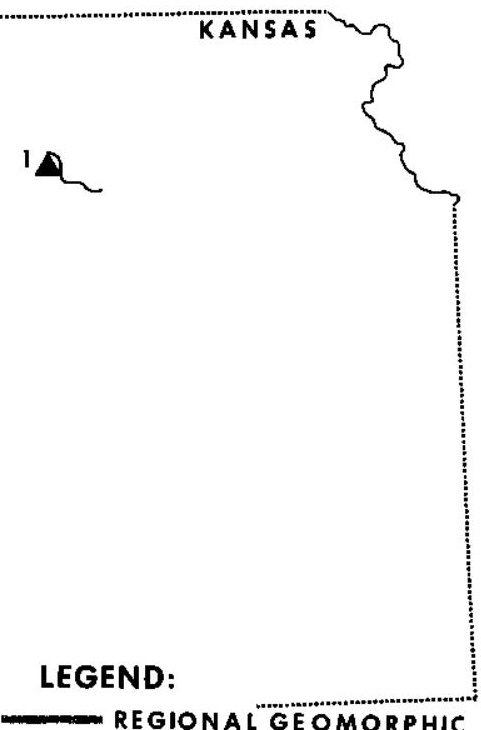

REGIONAL GE OMORPHIC LINEAMENT

LINEAMENT

SPACIALLY CORRELATED

WITHURANIUM OCCURENCES

OUTSIDE OF THIS MAP AREA

(FROM SAUNDERS, 1974)

$\triangle$ STUOY lOCALITY

- ROADTRAVERSES

- PROJECT B OUNDARY

- URANIUM OCCURENCE

PROJECTION: ALBERSEOUAL AREA

Figure IV-1. Road Traverses and Study Localities 
decreases still further the usefulness of surface traverses because the sands tend to mask any anomalies that may be present in the underlying soils.

Despite these difficulties, however, it will continue to be necessary to make road traverses and field measurements in areas where anomalies are suspected.

Experience during this study bears out the conclusion of Lovborg (1973) that the 2 in. $x 2$ in. detector must generally be considered inadequate in sensitivity for use in a field spectrometer, and it is recommended that at least a 3 in. $x 3$ in. detector be used in any future field studies.

Emanometer measurements or hydrogeochemical techniques may ultimately prove to be the most valuable in locating concentrations below the present soil surfaces (Miller and Ostle, 1973; Dyck, 1969, 1972, 1975).

Furthermore, botanical methods may also aid in location of favorable zones which can then be subjected to detailed evaluation by drilling (Cannon and Kleinhampl, 1956; Cannon, 1957, 1960, 1964).

\section{B. TRAVERSES ACROSS REGIONAL LINEAMENTS}

Several traverses were made across regional lineaments (see Figure IV -1) to see if they could be detected by car-borne gamma-ray spectrometry. No anomalous readings were found that could be definitely associated with any of the lineaments, however, it was concluded that this is not a practical way to determine whether the lineaments are detectable by associated gamma radiation anomalies. A detailed airborne gamma-ray spectrometer survey should be undertaken to provide the required higher sensitivity and more thorough sampling of selected lineaments and their surroundings than can be done by surface gamma-ray spectrometer measurements (see also 
Section III.C. 1). The detection of radon migrating up the fracture zones by emanometry is anothe $r$ distinct possibility.

\section{DESCRIPTIONS OF INDIVIDUAL LOCALITIES (See Figu re IV - 1)}

\section{Locality 1}

Kimberlite pipes occur at several locations in Riley County in north central Kansas (Brookins, 1970). A field radiometric survey showed that the intrusive which outcrops near the town of Bala is anomalously radioactive. It shows activities in excess of four times the background measured on adjacent Permian shales. Another kimberlite intrusive located near Leona rdville shows only about half the radioactivity of the Bala pipe, but it is still substantially above the background of surrounding rocks. Since the locality is outside the study area, it has not been explored in detail. It appears possible that these intrusives may be similar to alkaline basalt diatremes found in the Colorado Plateau which sometimes contain uranium deposits and nearly always appear to be anomalously radioactive (Shoemaker, 1955). If so, then further exploration is certainly warranted.

\section{Locality 2}

Approximately 58 miles east of the study area, at Kanapolis State Lake, radiation levels in excess of 10 times background were discovered in coarse-grained sandstone beds outcropping at water level on the east side of the lake. The radioactive rocks were found near the center of a channel sandstone which also incorporates small fragments of dark carbonaceous material. Limonite nodules and masses of marcasite are abundant in the clay shales which flank the channel. At this locality, the Dakota Formation is overlain by gravels of Ogallala age and the gamma radiation readings from these gravels are one and one half to two times higher than those found in the oxidized outcrops of the Dakota sandstones. Since the area is also underlain 
by thick layers of bedded salt which would prevent upward migration of uranium bearing solutions, it appears most likely that uranium released by the decomposition of minerals in the Ogallala has been concentrated at geochemically favorable locations in the Dakota channel.

A detailed examination of this channel was not made because it lies outside the study area, and such a program would be beyond the scope of the present project. We did, however, cooperate with the Kansas State Geological Survey in making several test drillings in the channel. Highly radioactive zones a few feet thick were found in several of the holes and cores were taken. The uranium concentrations in the radioactive zones are now under study by the Kansas Geological Survey.

The presence of this type of deposit in a channel sandstone along the eastern edge of the Dakota outcrop suggests that further exploration is warranted. An airborne survey of the area followed by surface checking of anomalies and ultimately test drilling in promising localities should be undertaken.

\section{Locality 3}

Outcrops of the Smoky Hill member of the Niobrara Chalk show anomalous radioactivity over a wide area in Gove County, Kansas. The radiation levels are about twice that of the associated shale beds and three to four times higher than chalk of the same age and stratigraphic position in eastern Colorado. Small faults and fractures in chalk outcrops in western Gove County show evidence of still greater localized enrichment. Although no substantial concentrations of radioactive minerals were detected, it should be noted that Gove County shows anomalies in the Dakota in the subsurface (see Section II) and also shows anomalously high uranium in surface and groundwaters (Landis, 1960). 


\section{Locality 4}

The lower portion of the Pierre Shale outcrops along State Highway 25 about 6 miles west of Russell Springs in Logan County, Kansas. This zone shows a background radioactivity at least three times higher than the shales in the upper Pierre as measured with our field instruments. This anomalous concentration is very widespread and occurs in the subsurface in northwestern Kansas and in southwestern Nebraska (see Tourtelot, 1956; Landis, 1959; and Swanson, 1960).

The radioactive zone appears to be much less prominent in east-central Colorado and cannot be detected in southeastern Colorado. The activity may be related to the presence of bands of small phosphatic concretions.

\section{Localities 5 and 6}

Outcrops of volcanic ash are anomalously radioactive adjacent to the road at Locality 5 on State Highway 23 about 2 miles east of Crooked Creek. The volcanic ash beds show background count rates roughly three times higher than the soils overlying them. Locality 6 is located in a roadcut on U.S. Highway 160 in Clark County, 23 miles east of Meade. Local concretionary masses of opalized volcanic ash show anomalous radioactivity.

\section{Locality 7}

Approximately 9 miles north of Farley on New Mexico Highway 193 in Colfax County, large masses of dark greenish to greenish gray igneous rocks form a small mountain west of the road. Similar rocks also outcrop 3 to 5 miles east of this locality along the western edge of Union County. Feldspathoids forming phenocrysts are scattered sparingly throughout the rock. The entire igneous body is anomalously radioactive showing count rates 
four to five times higher than the backgrounds measured on surface soils near the outcrops. A detailed study could not be conducted at the time of examination, but the area should be examined further to determine whether local concentrations of radioactive minerals might be present.

\section{Locality 8}

The Morrison Formation forms a series of prominent outcrops along a road on State Highway 18 about 2 miles south of the junction with State Highway 325 in Union County, New Mexico. The locality is about 5 miles southwest of Kelton, Oklahoma. Localized concentrations of radioactive minerals occur in blocky shale beds where they form thin dark brown coatings on vertical fractures in the shale. These concentrations are most prominent at the north end of the roadcut.

\section{Locality 9}

Redbeds of the Whitehorse Formation outcrop along the shores of Lake Meredith just north of Sanford Dam in Hutchinson County, Texas. In some parts of the section above the water level, local greenish splotches can be found, and these frequently show substantially increased count rates over the adjacent redbeds. A thorough search of the area could not be made, but it might be expected that some radioactive concentrations could occur. 

SECTION V

SUMMARY OF CONCLUSIONS

\section{A. GAMMA-RAY WELL LOG DATA}

The western portion of Kansas has provided a test area for the development of a new method of outlining potential uraniferous provinces in the subsurface. The gamma-ray logs from oil or gas wells or exploratory holes have been subjected to trend surface analysis, computer contouring, and statistical evaluation outlining areas of anomalously high gamma-ray activity in the Dakota and Morrison formations. The most prominent of these are located in central western Kansas whe re they correlate quite well with areas of high uranium content in the shallow groundwaters (Landis, 1960). No ore-grade readings were obtained, but some groups of wells showed high readings as great as $50 \mathrm{ppm}$ eU. Examination of the maps showed that in some cases vertical stacking of anomalies in the Morrison, the base of the Dakota, and the top of the Dakota occurs and in others it does not.

Examination of other well logs throughout the remainder of the study area has identified other potentially favorable beds and general geographic areas which may contain deposits.

It is concluded that gamma-ray logs from wells drilled for petroleum exploration are valuable aids in delimiting uraniferous provinces in subsurface formations. Since this type of information is gathered on a routine basis in many parts of the world, it appears that it should serve as a valuable new technique for uranium evaluation in these areas.

\section{B. REGIONAL LANDSAT (ERTS) LINEAMENT STUDY}

In attempting to link the uraniferous provinces with geologic factors which might influence their distribution, several possible correlations 
were discovered. It was found that the anomalies located by this technique are related to lineaments visible on the surface in earth satellite image ry. The spatial association of lineaments with uranium deposits is thought to be caused by the lineaments acting as vertical transmission paths for mineralizing groundwater. The groundwater in the western portion of the study area is known to contain anomalously high values of uranium, and downward percolation of this water into formations where conditions of chemical reduction occur could result in some of the observed anomalies.

\section{RELATIONSHIP OF ANOMALIES TO SALT BEDS}

The area of anomalous well log readings is underlain by thick beds of salt which is sufficiently plastic that fractures cannot remain open. Since the salt has not dissolved, it is clear that any uranium which is present must either be penecontemporaneous or from downward migration of uranium-bearing solutions. An examination of the anomaly maps shows that the largest contiguous anomalies are located over one of the main salt bodies and are approximately coincident with its margins. This suggests that the salt acted as a barrier to downward percolating waters, and its presence may be an important factor in the genesis of any uranium concentrations which may be present. 
SECTION VI

RECOMMENDATIONS FOR FUTURE INVESTIGATIONS

A. GENERAL

A full evaluation of the uranium resource potential of the study area has not been completed and, in fact, could not be accomplished within the time, budget, equipment, or personnel constraints of this research program. New methods for data evaluation have been developed and uraniferous provinces have been defined. Potential geological relationships between the uraniferous provinces and geomorphic lineaments as well as subsurface salt bodies have been discovered. Nevertheless, this study would be incomplete without a consideration of the problems which remain unsolved and some suggestions as to potential methods for obtaining practical solutions.

\section{B. EXTENSION OF GAMMA-RAY WELL LOG DATA EVALUATION}

Uraniferous provinces based on gamma-ray well log data have been defined only in Kansas. Obviously, this technique should be expanded to cove $r$ the entire study a rea and to include more stratigraphic units. Formations other than the Dakota and Morrison should be tested and might prove to be of more potential value. Zones in the Whitehorse Formation of upper Permian age have been found to show high levels of radioactivity in some wells in both Kansas and Nebraska, and this zone should be examined in detail. The Pierre Shale and portions of the Niobrara Chalk sequence also show anomalous radioactivity. Several Tertiary clastic units merit examination over a broad area. Extension of the gamma-ray well log study over the entire area would aid g reatly in further defining potential uraniferous provinces and would facilitate more systematic exploration planning.

In addition to the gamma-ray well log study, an investigation of the relationships between lithofacies and gamma-ray anomalies should be 
undertaken over the entire area. This is essential to the understanding of the potential effect of sedimentary environment upon the genesis of uranium concentrations. Such a study could be accomplished with geophysical and sample logs already available. This would be particularly valuable in planning any future drilling prog ram.

\section{DRILLING AND SAMPLING PROGRAM}

As soon as the comprehensive well log study is underway, a drilling program should be started to evaluate those anomalies which have been discovered by this investigation. Selected formations should be cored and detailed analysis of the cores should be made to confirm that the anomalies are truly due to uranium. Core petrography and sedimentary environment studies will also be required to provide a full evaluation of the potential of specific formations to serve as host rocks for uranium deposition. Such a core analysis program would be necessary if full utilization of the drilling program is to be had. The drilling program should be started in the next field season and core analysis should begin as soon as possible.

Apparatus which permits rapid and accurate determination of radioactive equilibrium should be used to study deposits in the zones of leaching near the surface. It is already obvious that uranium is moving in present ground and surface waters, and it is imperative to know its source and ultimate fate in the hydrologic system of the area.

A comprehensive water sampling study should be set up and carried out over a three-year period to aid in determining sources and rates of uranium release from potential source beds during different seasons of the year.

Although correlations between lineaments and radiation anomalies and between uraniferous provinces in the Dakota and Morrison and the 
underlying salt bodies have been suggested, a rigorous test of the se relationships is still needed. This should include data from core drilling and water analyses together with a more thorough water sampling program. In addition, an understanding of the influence of brine composition on uranium transport in ground and formation waters is required. Any information obtained as a result of this study would have broad application outside the specific region under investigation.

\section{GEOBOTANICAL STUDY}

A geobotanical study is particularly appropriate in the Great Plains environment. Prairie plants tend to have much deeper root systems than plants living in wet climates, and they can often provide a sample of chemical constituents present well below the zone involved in agricultural activities. A specific search for indicator plants in the area might prove to be especially useful. This study, coupled with low-level aerial photography to aid in rapid scanning of broad areas, might yield very valuable information and would be relatively inexpensive.

\section{E. AIRBORNE GAMMA-RAY SPECTROMETRY}

This region of the Central Great Plains should be surveyed by airborne gamma-ray spectrometry to determine whether surface anomalies can be correlated with anomalies in subsurface units, and to search for surface leached areas which may occur along lineaments and provide clues to possible underlying deposits in the form of low $U / T h$ ratios or for high U/Th ratios if radon is concentrated in the lineaments. Since such a survey is already planned, it should receive a high priority and its date of completion should be advanced as far as possible.

\section{F. SURF ACE SURVEYS}

Surface surveys must be continued and expanded to include emanometer measurements. Localized concentrations of uranium have been 
found in outcrops and these can only be evaluated by ground-based survey methods. Furthermore, outcrops are good in a few portions of the study area, and ground surveys are the cheapest and most practical method for obtaining information about the exposed rocks.

\section{G. EXPANSION OF STUDY AREA}

Finally, it is suggested that the actual study area be modified somewhat in outline. From the point of view of physiography and geology, it appears most reasonable to extend it westward to the Front Range. This would make the western boundary roughly equivalent to the 105th meridian. In view of the fact that Kansas al ready makes up a substantial portion of the total a rea and considering the ready availability of data from all of Kansas through the Kansas State Geological Survey, it would improve efficiency to expand the eastern boundary to include the entire state. 


\section{SECTION VII}

\section{REFERENCES}

Baldwin, B. and W. R. Muehlberger. 1959. Geologic studies of Union County, New Mexico: State Bureau of Mines and Mineral Resources, Bull. 63, $171 \mathrm{p}$.

Bradshaw, R. L. and W. C. McClain. 1971. Project salt vault: A demonstration of the disposal of high-activity solidified wastes in underground salt mines, ORNL4555 (Oak Ridge National Laboratory), 360 p.

Branson, C.C., A. L. Burwell and G. C. Chase. 1955. Uranium in Oklahoma, 1955: Oklahoma Geological Survey, Mineral Report No. 27, Norman, Okla., 22 p.

Brookins, D. G. 1970. The kimberlites of Riley County, Kansas: Kansas State Geological Survey, Bull. 20, 32 p., Lawrence, Kan.

Butler, A. P., Jr., W.I. Finch and W.S. Twenhofel. 1962. Epigenetic uranium deposits of the United States, USGS Map MR -21; Washington, D. C.

Cannon, H. L. and F.J. Kleinhampl. 1956. Botanical methods of prospecting for uranium: In Proc. 2nd U.N. Internat. Conf. Peaceful Uses of Atomic Energy, Geneva, 1955, v. 6, p. 801-805, United Nations, New York; Also in USGS, P rof. Paper 300, p. 681-686.

Cannon, H. L. 1957. Description of indicator plants and methods of botanical prospecting for uranium deposits on the Colorado Plateau: USGS Bull. $1030 \mathrm{M}$, p. 399-516.

Cannon, H. L. 1960. The development of botanical methods of prospecting for uranium on the Colorado Plateau: USGS Bull. 1085A, p. 1-50.

Cannon, H. L. 1964. Geochemistry of rocks and related soils and vegetation in the Yellow Cat area, Grand County, Utah: USGS Bull. 1176, 127 p.

Cooper, M. 1953. Bibliography and index of literature on uranium and thorium and radioactive occurrences in the United States - Part 1: Arizona Nevada and New Mexico; GSA Bull., v. 64, p. 197-234.

Cooper, M. 1954. Bibliog raphy and index of literature on uranium and thorium and radioactive occurrences in the United States - Part 3: Colorado and Utah; GSA Bull. , v. 65, p. 467-589. 
Cooper, M. 1955. Bibliog raphy and index of literature on uranium and thorium and radioactive occurrences in the United States - Part 4: Arkansas Iowa, Kansas, Louisiana, Minnesota, Missouri, Nebraska, North Dakota, Oklahoma, South Dakota and Texas: GSA Bull., v. 66, p. 257-326.

Curtis, N.M. 1956. Some facts about Oklahoma u ranium, Oklahoma Geology Notes, v. 16, n. 10, p. 106-120: Oklahoma Geological Survey, Norman, Oklahoma.

Darnley, A. G. 1973. Airborne gamma-ray techniques - present and future; U ranium Exploration Methods; Proc. of a Panel, Vienna, 10-14 Apr 1972; International Atomic Energy Agency, Vienna. p. 67-108.

Dyck, W. 1969. Development of uranium exploration methods using radon: Geological Survey of Canada, Paper 69-46; Ottawa, 26 p.

Dyck, W. 1972. Radon methods of prospecting in Canada; in Uranium Prospecting Handbook (S.H.U. Bowie, et al., eds.): The Institution of Mining and Metallurgy, London, p. 212-241.

Dyck, W. 1975. Geochemistry applied to uranium exploration: Geological Survey of Canada, Paper 75-26, p. 33-47.

Elkins, T.A. 1940. The reliability of geophysical anomalies on the basis of probability considerations: Geophysics, v. 5, no. 4, p. 321-326.

Everhart, D. L. 1958. Summary of unsolved problems and new trends in uranium geology: Proc. 2nd U.N. Intern. Conf. on Peaceful Uses of Atomic Energy, v. 2, p. 310-314.

Finch, W.I. 1967. Geology of epigenetic uranium deposits in sandstone of the United States: USGS Prof. Paper, 538, Washington, D. C. 121 p.

Finch, W. I., I. S. Parrish and G. W. Walker. 1959. Epigenetic uranium deposits in the United States: USGS Map I-299. Washington, D.C.

Finch, W. I. , J. C. Wright, and M. W. Sullivan. 1975. Selected bibliog raphy pertaining to uranium occurrences in eastern New Mexico and west Texas and nearby parts of Colorado, Oklahoma and Kansas; USGS, Denver, Colo.; Doc. No. PB-241 629; Avail from: National Technical Information Service, U.S. Dept. of Commerce; P.O. Box 1553, Springfield, Va.

Finnell, T. L. and I. S. Parrish. 1958. Uranium deposits and principal orebearing formations of the Central Cordilleran foreland region: USGS Map MF-120, Washington, D.C. 
Freden, S.C. et al., eds., 1974. Third Earth Resources Technology Satellite Symposium. Vo. II, NASA SP-356: Goddard Space Flight Center, Washington, D.C. (Avail. from Superintendent of Doc. U.S. Govt. Ptg. Off., Wash., D. C., 20402.)

Gott, G. B. and J.W. Hill. 1953. Radioactivity in some oil fields of southeastern Kansas: USGS Bull. 988-E, p. 69-121.

Hathaway, L. R., L. M. Magnuson, B. L. Carr, O. K. Galle, T. C. Waugh. 1975. Chemical quality of irrigation waters in west-central Kansas: Kansas Geological Survey, Chemical Quality Series 2, Lawrence, Kansas, $46 \mathrm{p}$.

Hobbs, S. W. and V.C. Fryklund, Jr. 1968. The Coeur d'Alene District, Idaho; Ore deposits of the United States, 1933-1967 (J. D. Ridge, ed.): AIME, New York, N.Y. p. 1417-1435.

Johnson, K.S. 1969. Mineral Map of Oklahoma (Exclusive of oil and gas fields) - Oklahoma Geological Survey, Map GM-15, Norman, Oklahoma.

Krusiewski, S.V. 1970. Selected bibliography on radioactive occurrences in the United States; Report No. RME-4110, TID UC 51: U.S. Atomic Energy Commission, Raw Materials Div., Washington, D.C., 136 p.

Kulstad, R. O. 1959. Thickness and salt percentage of the Hutchinson salt in Kansas: Kansas Geological Survey Bull. 139, p. 241-247.

Landis, E.R. 1959. Radioactivity and uranium content, Sharon Springs Member of the Pierre Shale, Kansas and Colorado: USGS Bull. 1046L, p. 299-318.

Landis, E.R. 1960. Uranium content and ground and surface waters in a part of the Central Great Plains: USGS Bull. 1087G, p. 223-258.

Landwehr, W.R. 1967. Belts of major mineralization in the western United States: Econ. Geol., v. 62, n. 4. p. 494-501.

Lovborg, L. 1973. Future development in the use of gamma-ray spectrometry for uranium prospecting on the ground; in U ranium Exploration Methods; Proc. of a Panel, Vienna, 1972: International Atomic Energy Agency, Vienna, p. 141-153.

Malan, R.C. 1972. Summary report - distribution of uranium and thorium in the Precambrian of the Western U.S.: U.S. Atomic Energy Commis sion, Rpt. AEC-RD-12: Grand Junction, Colo., 59 p. 
Miller, J.M. and D. Ostle. 1973. Radon measurement in uranium prospecting; in U ranium Exploration Methods, Proceedings of a Panel, p. 237-245: International Atomic Energy Agency, Vienna.

Mudge, M.R. 1967. In McKee, E. D., Oriel, S.S., and others, Paleotectonic investigations of the Permian system of the United States: USGS Prof. Paper 515, p. 97-123.

Nininger, R. D. 1954. Minerals for Atomic Energy; D. Van Nostrand Co. Inc., New York, p. 150.

Pierce, A.P., G. B. Gott, and J.W. Mytton. 1964. Uranium and helium in the Panhandle gas field, Texas and adjacent areas: USGS Prof. Paper $454 \mathrm{G}$, p. G1-G57.

Saunders, D.F., G. E. Thomas, F.E. Kinsman and D. F. Beatty. 1973. ERTS imagery use in reconnaissance prospecting; Final Rpt., Contract NAS 5-21796; NASA Goddard Space Flight Center: Texas Instruments Incorporated, Dallas, Texas, (Avail. from National Technical Information Service, U.S. Dept. of Commerce, P.O. Box 1-53, Springfield, Va. 22141 , as Doc. No. E74-10345)

Saunders, D.F. 1974. ERTS data interpretation in petroleum and mining exploration; ERTS-based nonexclusive morphostructural analysis map series: Exploration Services, Services Group, Texas Instruments Incorporated, Dallas, Texas.

Schlumberger, 1972. Log interpretation - principles; Vol. I., chapter 10, gamma-ray logs. p. 57-59. Schlumberger Ltd., New York.

Schumaker, R.D. 1966. Regional study of Kansas Permian evaporite formations: Unpub'd M.S. thesis, Wichita State Univ., p. 87.

Scott, R.C. and F.B. Barker. 1958. Radium and uranium in groundwater in the United States: Proc. 2nd U.N. Intern. Conf. on Peaceful Uses of Atomic Energy, v. 2, p. 153-177.

Shoemaker, E. M. 1955. Occurrence of uranium in diatremes on the Navajo and Hopi Reservations, Arizona, New Mexico and Utah: USGS Prof. Paper 300, p. 179-185.

Stokes, W. L. 1968. Relation of fault trends and mineralization, eastern Great Basin, Utah: Econ. Geol. v. 63, no. 7, p. 741-759. 
Swanson, V.E., 1960. Oil yield and uranium content of black shales: USGS Prof. Paper 356-A, Washington, D. C. $44 \mathrm{p}$.

Texas Instruments Incorporated. 1974. Airborne geophysical survey, Wind River Basin area, Wyoming, U.S. AEC Contract No. AT(05-1)-1631, AEC Serial No. GJO-1631-1.

Tourtelot, H.A. 1956. Radioactivity and uranium content of some Cretaceous shales, Central Great Plains: Am. Assoc. Pet. Geol., Bull 40, p. 62-83.

Tweto, O. and P.K. Sims. 1963. Precambrian ancestry of the Colorado Mineral Belt: Geol. Soc. Am. Bull., v. 74, p. 991-1014.

Wertz, J.B. 1970. The Texas lineament and its economic significance in southeast Arizona: Econ. Geol., v. 65, no. 2. p. 161-181. 

APPENDIX A

STATISTICAL ANALYSIS OF PLATE II-6, NEAR SURFACE GAMMA-RAY WELL LOG ANOMALIES

An attempt has been made to determine whether the near surface gamma-ray well log anomalies can be related to lineament zones. In testing this potential relationship, it has been assumed that each lineament zone has a total effective width of 5 miles. Therefore, any well which 1 ies within 2.5 miles of the center line of the lineament plotted on the map is considered to be within the zone of potential geological influence of the lineament. It is recognized that this type of assumption constitutes a major oversimplification of the actual condition. Obviously the true effective width of the fracture zones associated with lineaments may vary greatly at specific points along their length. Nevertheless, an average lineament width of 5 miles does appear to be reasonable and based upon this assumption the following results have been obtained.

Total number of wells recorded on map 338

Total of all wells located within lineament zones 102

Total of all wells showing anomalies

Total anomalous wells in lineament zones

- $24 \%$ of all of the wells drilled in lineament zones show anomalies.

- $14 \%$ of all of the wells drilled outside lineament zones show anomalies.

Although it is obvious that a larger total sample is needed, the data does imply a positive correlation between the shallow radioactive anomalies and lineament zones. If the gamaray well log studies are expanded in the future, a valuable test of the significance of these results could be expected. 



\section{APPENDIX B}

\section{CHEMICAL ANALYSIS DATA}

$$
\text { Chemical analyses for } U_{3}{ }_{8} \text { were performed by the }
$$
Bendix Field Engineering Corporation which serves as contractor to the ERDA office at Grand Junction, Colorado. The results obtained are listed as follows:

Locality $2,($ IV-4) Ellsworth Co., Kansas, channel in Dakota Sandstone.

Locality 6 , (IV-6) Clark Co., Kansas, concretionary mass of opal and cristobalite. $\quad 150 \mathrm{ppm}$

Locality 7 , (IV-6) near boundary between Colfax and Union Co., New Mexico, greenish extrusive igneous rock. 



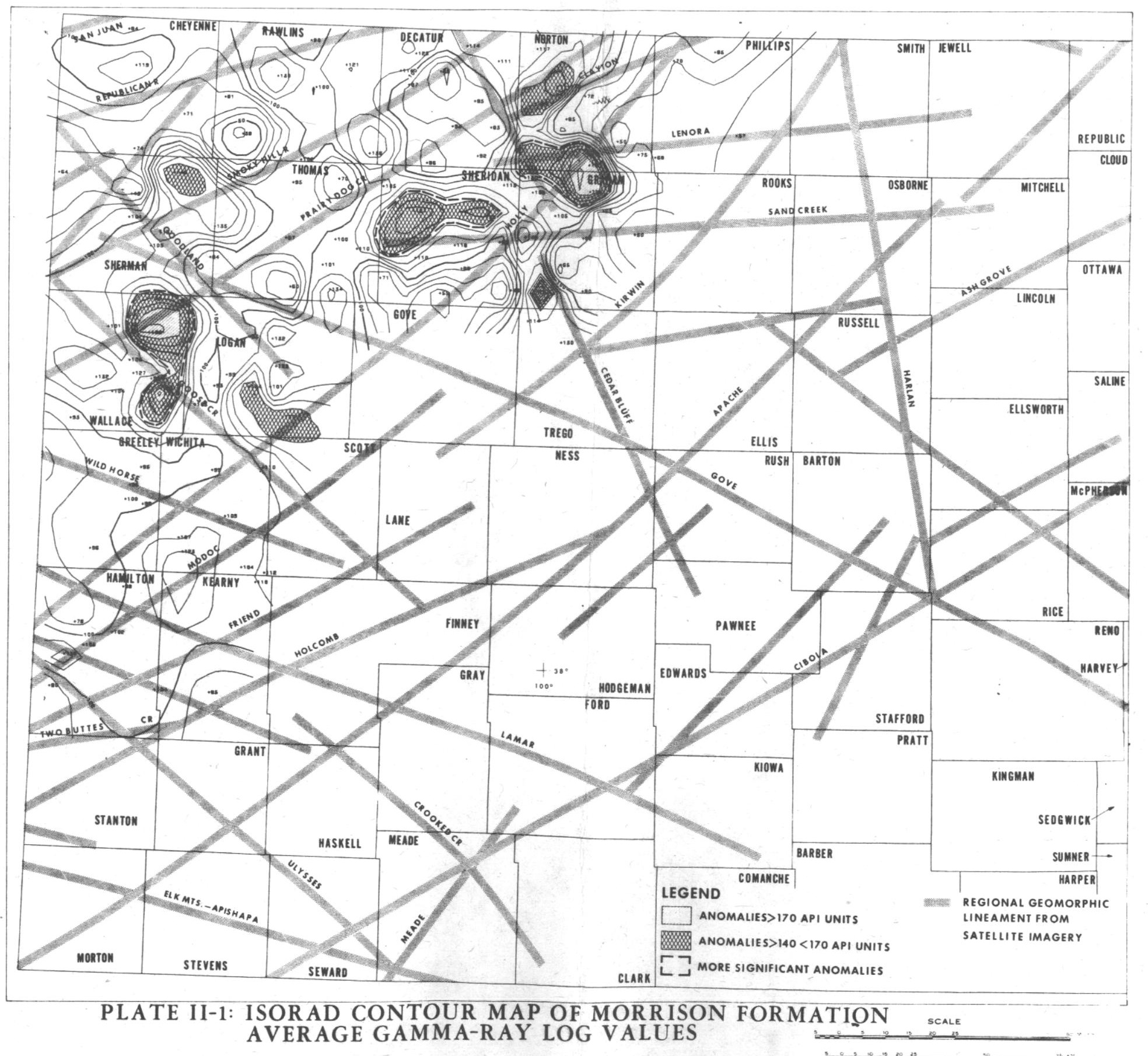





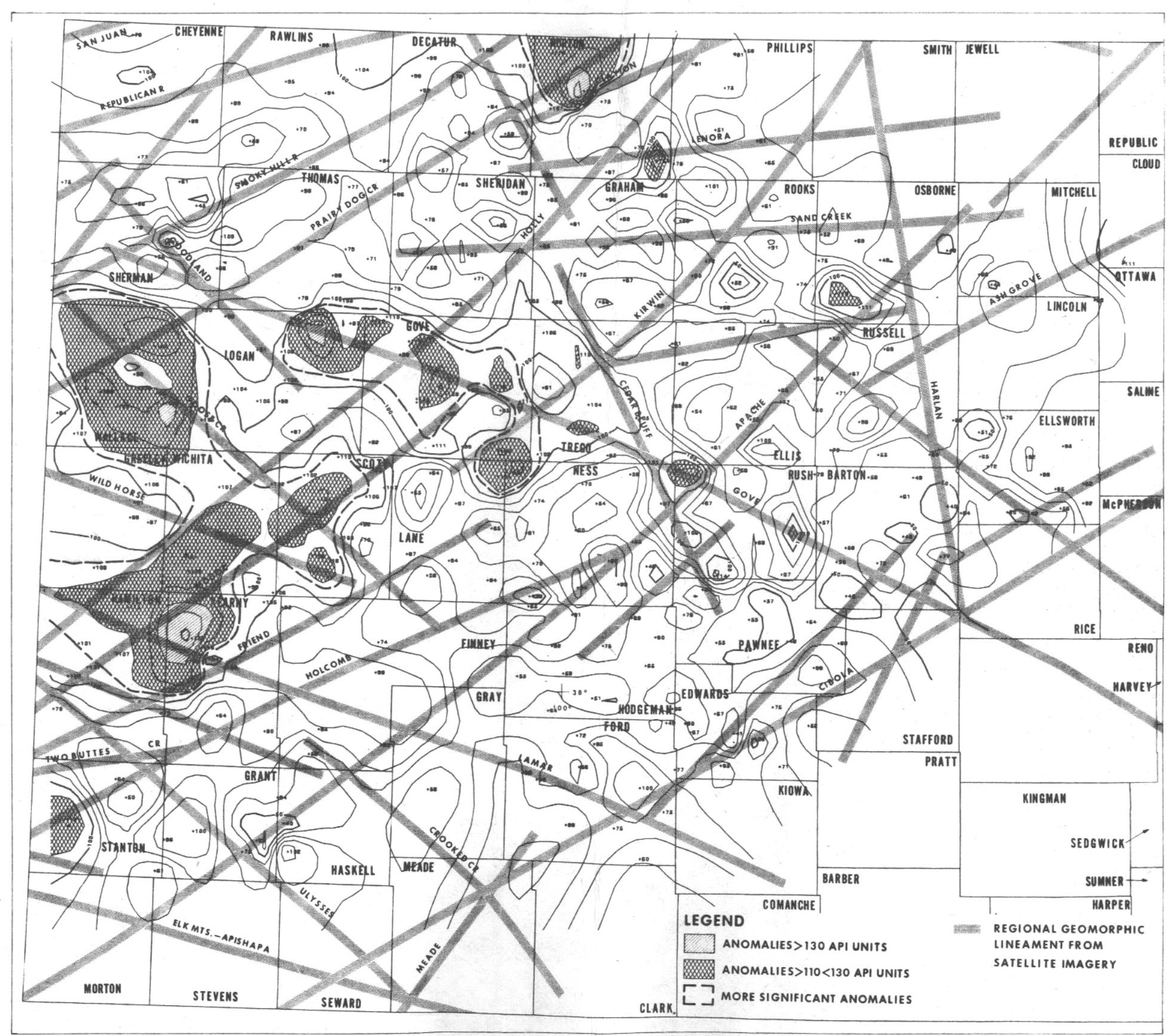

PLATE II-2 ISORAD CONTOUR MAP OF DAKOTA

FORMATION AVERAGE GAMMA-RAY LOG

SCALE VALUES 



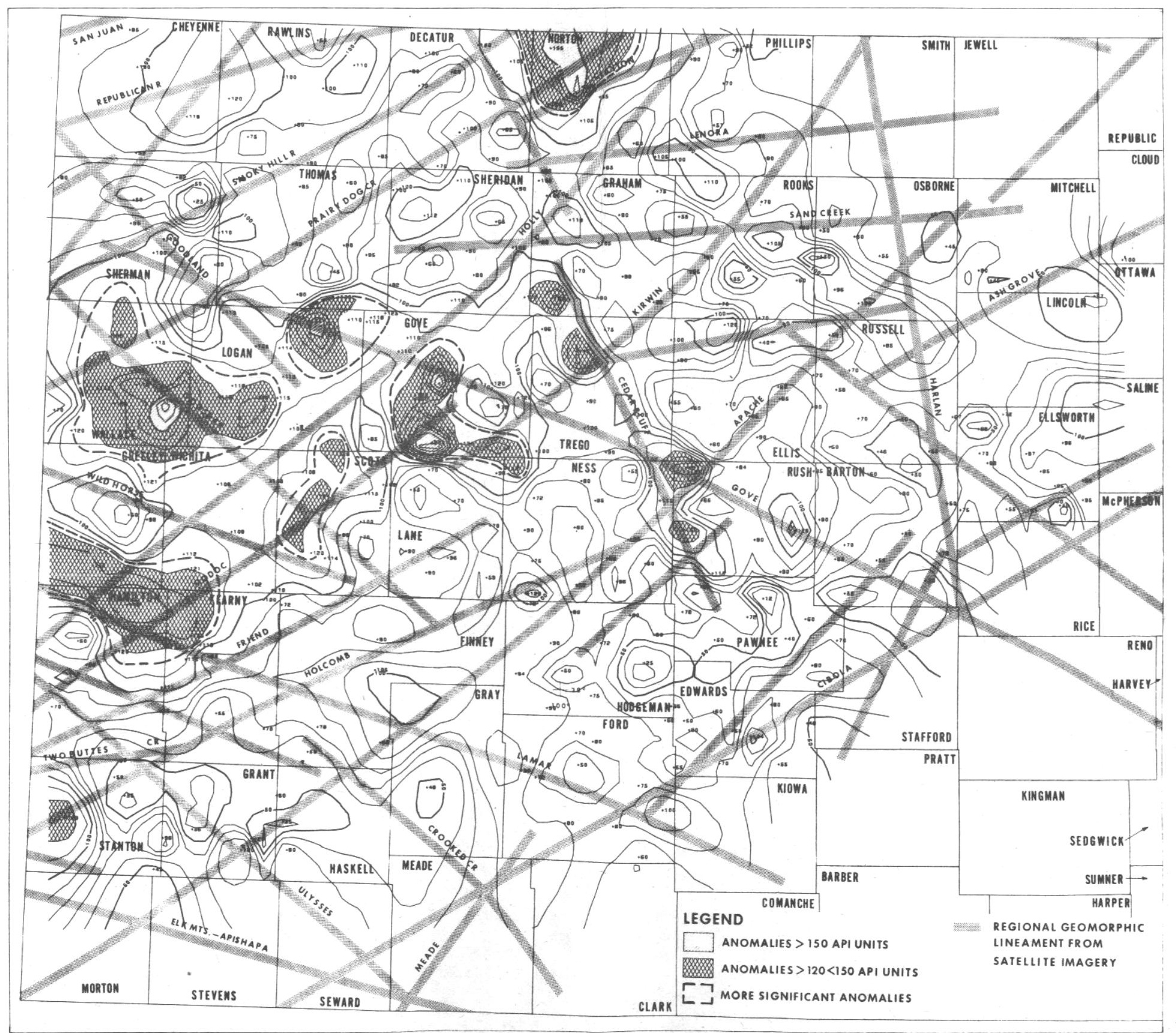

PLATE II-3 ISORAD CONTOUR MAP OF GAMMA RAY LOG SCALE VALUES FOR TOP PORTION OF THE DAKOTA FORMATION 



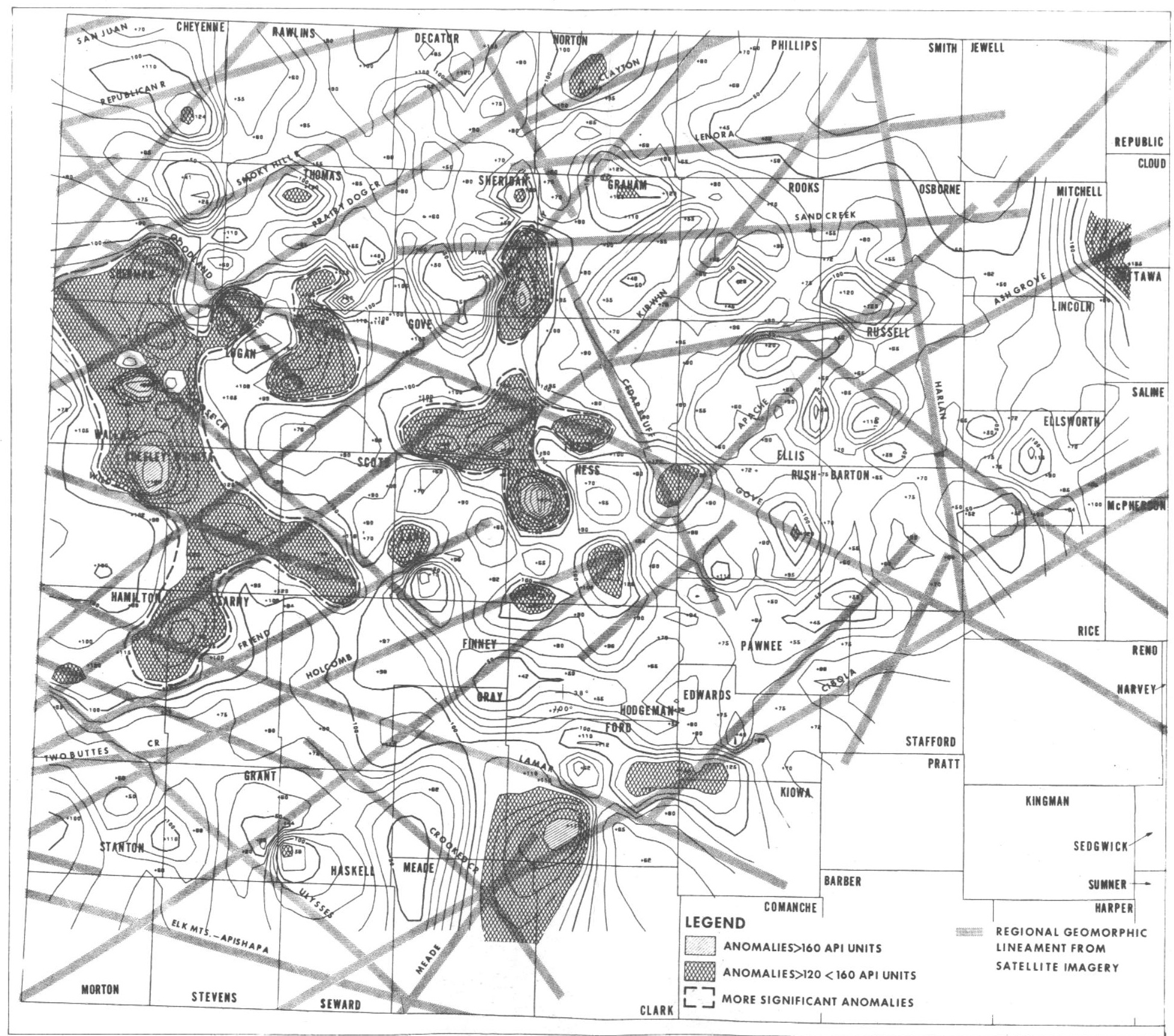

PLATE II-4 ISOR AD CONTOUR MAP OF GAMMA RAY VALUES FOR BOTTOM PORTION OF THE DAKOTA FORMATION 



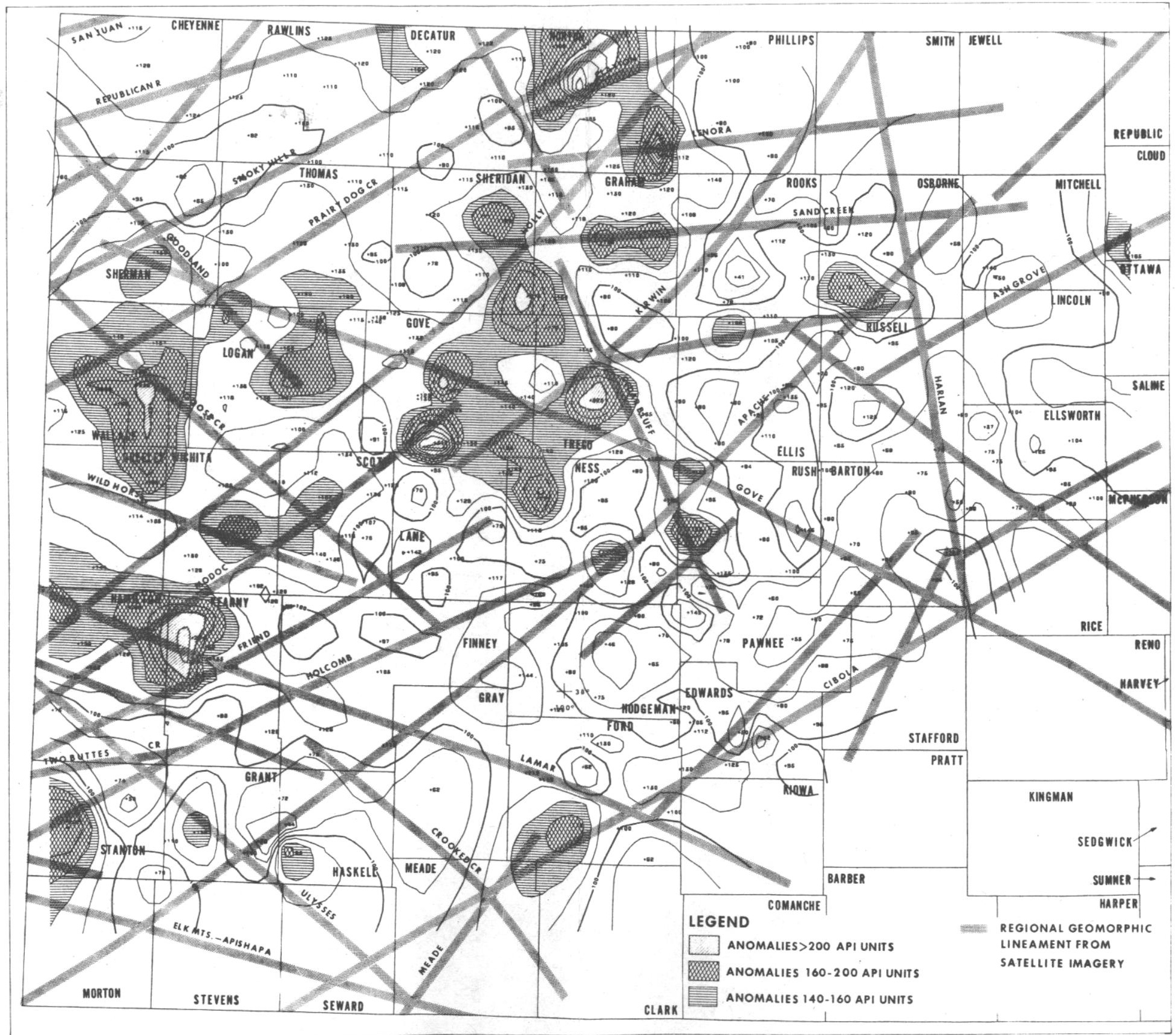

PLATE II-5 HIGHEST GAMMA-RAY LOG VALUES IN THE DAKOTA FORMATION

sCALE 
4 


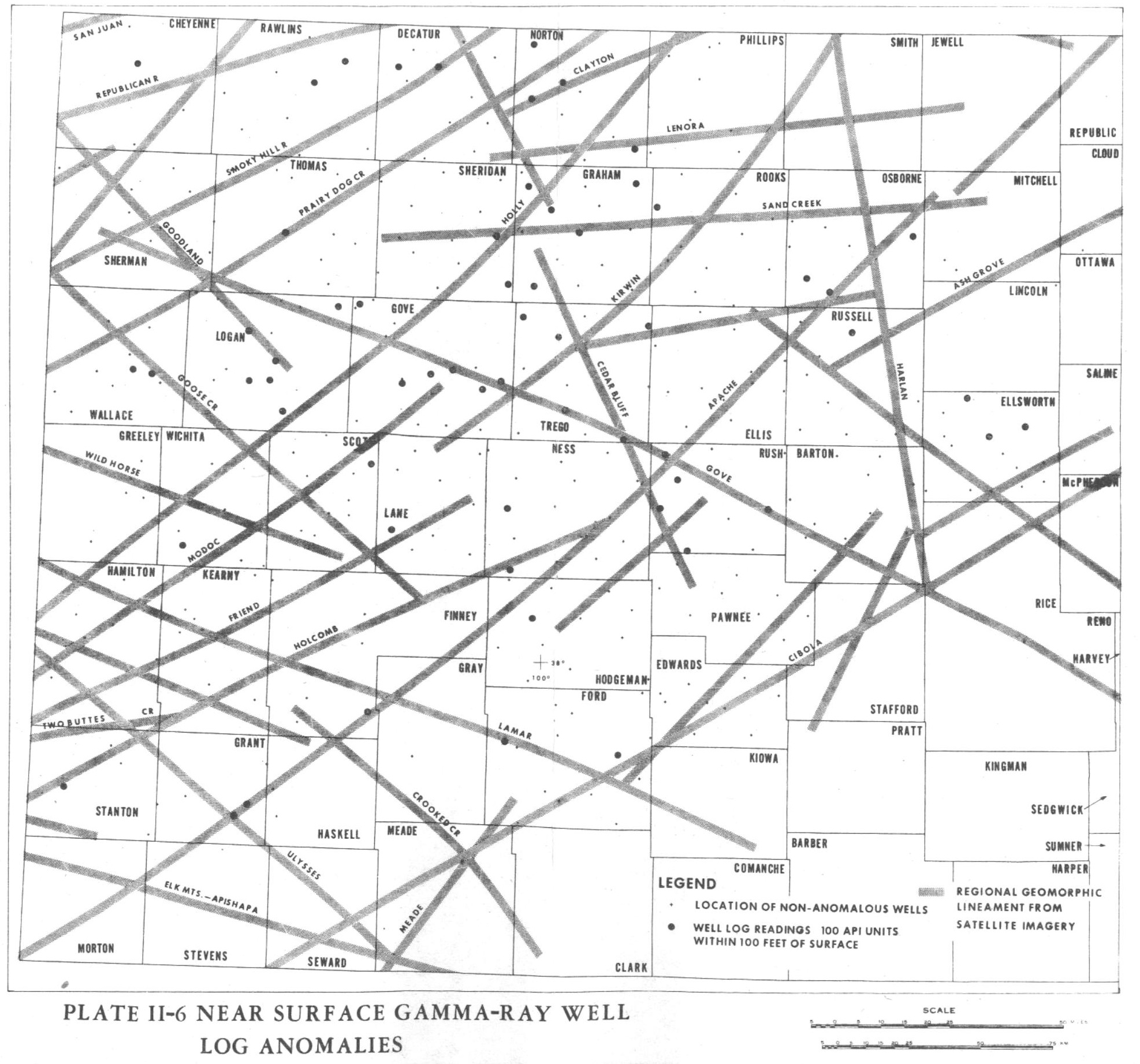




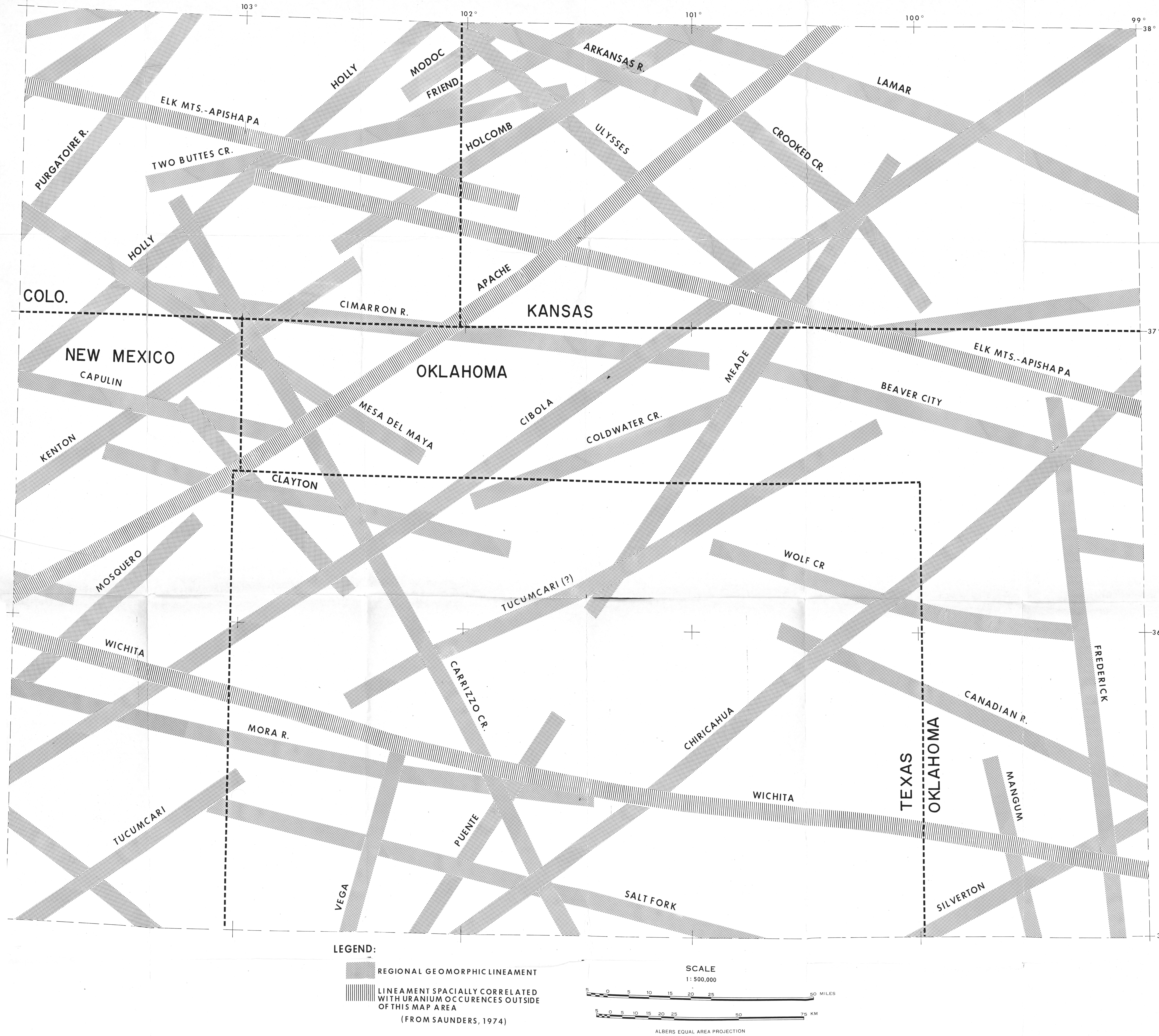

PLATE III-2 REGIONAL LANDSAT ERTS GEOMOR PHIC LINEAMENT MAP SOUTH PART OF STUDY AREA

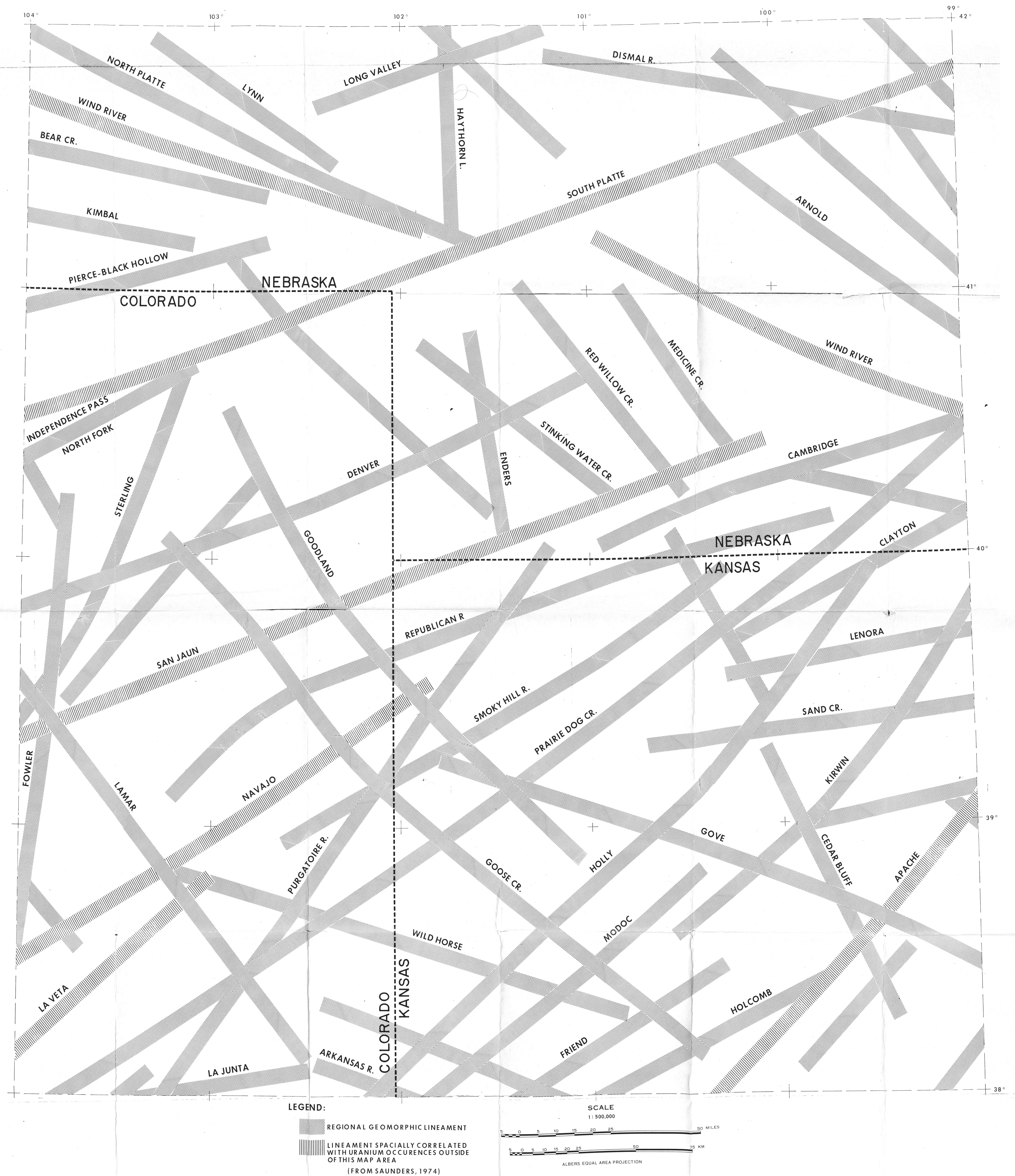






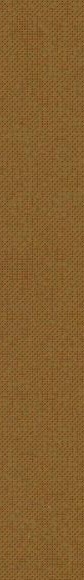

